\title{
A ACIDENTADA MORFOLOGIA DO PROCESSO ELEITORAL BRASILEIRO: ELEIÇÕES GERAIS DE 2002
}

\author{
Mônica Herman Salem Caggiano \\ Professora Doutora do Departamento de Direito do \\ Estado da Faculdade de Direito da Universidade de \\ São Paulo
}

\begin{abstract}
Resumo:
O presente trabalho resulta de pesquisa que, sistematicamente, vem sendo atualizada, visando o exame do processo eleitoral brasileiro: o sistema adotado, a atuação dos elementos que o compõem, o comportamento do quadro partidário, etc. Tais fatores, que produzem influência direta sobre a qualidade da representação política, é que compõem os pontos a demandar especial atenção por parte dos analistas e sobre os quais debruça-se o estudo promovido tendo por cenário específico as eleições gerais de 2002.
\end{abstract}

\begin{abstract}
:
This article intends to discuss the general election held in Brazil in October 2002. The main task is to allow the reader to have a look upon this special and complex field that is represented by the electoral process. Indeed, here there are records about the Brazilian laws and the act settled for the purpose of regulating the electoral process. In addition the paper deals with issues specific to an electoral period, just as the electoral system, the problems involving the political parties, and the extremely sensible issue represented by the financial aspects of an electoral campaign.
\end{abstract}

Unitermos: processo eleitoral brasileiro; direito comparado

Notas Introdutórias

Em princípio, tem sabor de lugar comum discorrer sobre as eleições, de âmbito nacional, que marcaram o panorama político brasileiro em 2002. Isto porque, o tema já foi amplamente explorado pela mídia, até internacional, que, num tom jornalístico dissecou o pleito, apresentando os resultados e, também, os bastidores do processo de renovação política do Governo Federal e dos 27 Estados que compõem a nossa federação. No entanto, ressente-se a ausência de análise jurídica da mecânica e dos instrumentos utilizados para a realização dessa consulta popular que, a par de 
prestigiar a tradicional vocação para o voto, própria do povo brasileiro,' corresponde a um avanço no aprimoramento da democracia que vem sendo praticada sob a égide da Constituição de 1988.

Em verdade, de há muito, entre nós, é debatida a imposição de uma reforma política, ${ }^{2}$ direcionada, exatamente, ao aperfeiçoamento e robustecimento do modelo democrático desenhado pelos constituintes de 1988. Na medida em que este é preordenado pelo princípio da representação política, idéia constantemente reforçada, marginalizando-se os instrumentos de participação direta do povo, ${ }^{3}$ nada mais

1. A vocação para o voto já foi objeto de nossa análise em trabalho publicado sob o título: “ $O$ Cidadão Eleitor: O Voto e o Papel que Desempenha no Quadro Brasileiro", no livro "As Vertentes do Direito Constitucional Contemporâneo", sob a coordenação de Ives Gandra da Silva Martins (Estudos em homenagem a Manoel Gonçalves Ferreira Filho, Rio de Janeiro, América Jurídica, 2002), onde resta registrado: "Dentre tais elementos, sem dúvida, deve se destacar a verdadeira vocaşäo para o voto, hoje quase parte da indole brasileira, que, desde os primeiros tempos coloniais, era praticado a nivel local." E mais, é assinalado: '...Enfim, o exercício do voto, notadamente em esfera local, cra uma prítica bastante difundida, própria do modelo de organizaşão e administrașão municipal instalado pelos colomizadores portugueses, fenômeno que posiciona o sufrágio quase como un elemento inerente an espírito brasileiro, formatado ao longo dos anos. Em verdade, o sufiágio praticado em inumeros momentos compreendidos na trajetória histórica brasileira, não pode ser considerado como tendo, efetivamente, servido de instrumento eficaz à participação política - uma de suas essenciais funçöes - ou, ainda, de respaldo à construçäo de uma sociedade democrática, dirigida por governos legitimados, detentores do poder político por intermédio de "free and fair elections", que encontra no sufrágio universal unna de suas mais fortes formas de expressão. Certo é, contudo, que o exercicio do voto incorporou-se às tradiçöes brasileiras, independentemente do papel, da funçăo ou da importancia que lhe tenha sido conferida pela abundante legislação com que foi comtemplado. Posis bem, sem a pretensão de exaurir a matéria, este trabalho direciona-se à uma análise da trilha evolutiva do voto, notadamente quanto ao papel que vem desentpenhando, em território doméstico, para, afinal, verificar o atingimento do nível de "eleitorcidadão'", idéia forç̧a, hoje perseguida no ensejo de assegurarar a integralização do status da cidadania."

2. No tocante às medidas que integram a reforma política, recomenda-se ver a nota n. 28. Mais ainda, oportuno lembrar que, encerrado o período eleitoral $2002 \mathrm{e}$ inaugurado o Governo Lula (presidente Luís Inácio Lula da Silva) em $1^{\circ}$ de janeiro 2003, começaram os debates sobre as reformas necessárias. Juntamente com as questões da Previdência e a Tributária, a reforma política retornou ao cenário, por mais uma vez, proclamada como a mais relevante das revisões a cargo do Poder Legislativo. Encontramse aprovados pelo Senado os projetos que dispõem sobre: (1) fidelidade partidária (que impõe ao parlaınentar um vínculo de, pelo menos, 4 anos para poder obter legenda e concorrer a eleições); (2) a proibição de coligações partidárias para os pleitos proporcionais; (3) introdução de listas mistas (um tipo distrital, autorizando o eleitor a votar em candidato - voto nominal, mas também na legenda); (4) a proposta de financiaınento público das campanhas, projeto oriunda do Senado, de n. 353, de 1999, de autoria do Senador Sérgio Machado, com parecer favorável, que, no entanto, continua em tranitação seın qualquer definição quanto a sua futura e eventual transformação em lei.

3. Ao longo de quase 15 anos de aplicação da atual Constituição, pouco, muito pouco, tem sido praticada a participação na produção normativa por via de referendo, plebiscito ou iniciativa popular. Mesmo após a edição da Lei n. 9.709/98, que regulaınentou referidos institutos, o quadro não se alterou. Clássico e isolado, em nível de exemplo da interferência popular direta na textura do quadro norınativo, permanece a criação do preceito do art. 41-A, da Lei n. 9.504/97, introduzido por força da Lei n. 9.840 , de 28 de setembro de 1999, diploma resultante de iniciativa popular. 
apropriado do que o adequado alinhamento dos mecanismos operatórios deste standard à exigência de um padrão democrático que propicie um clima coroado pelo fenômeno denominado por Roberto Dahl de "responsiveness" - a “contínua correspondência do governo com as preferências de seus cidadãos considerados politicamente iguais"

A tanto, propõe-se o assinalado projeto reformulatório, que insere medidas incidentes sobre o quadro partidário, na perspectiva de sua redução e fortalecimento, para assegurar maior densidade representativa às agremiações políticopartidárias, e atinge, trazendo relevantes inovações, o sistema eleitoral acolhido, uma engrenagem que se apresenta superada, caminhando para a senilidade, o que se reflete de forma perversa no processo eleitoral, acarretando-lhe pontos de inconsistência e um desvio em acentuado grau. ${ }^{5}$

Considerando, no entanto, o fato de que as propostas revisionais, de perfil político, continuam estagiando na penumbra dos gabinetes parlamentares, prevalecendo um quadro legal já arcaico a cercar e orientar as eleições de outubro de 2002, pareceunos este merecedor de exame, ainda que perfunctório, a ensejar a identificação pontual de eventuais degenerescências e das facetas e instrumentos a reclamar reparos.

A preocupação com a análise eleitoral, enfocando em especial o pleito de 2002, tem amparo na própria relevância política dessa consulta, de índole nacional e formato gigantesco, a envolver cerca de 18.880 candidatos, que se estima terem percorrido aproximadamente 350 milhões de quilômetros ao longo da campanha; 2 milhões de pessoas mobilizadas pela Justiça Eleitoral a atuar no âmbito da consulta; 2.5 milhões de pessoas trabalhando pelos candidatos (delegados de partidos, fiscais, empregados de empresas de marketing, etc.). Enfim um momento eleitoral a envolver 5 bilhões de reais ${ }^{6}$ um elevadíssimo custo para ser suportado sem a garantia de resultados conformes às expectativas da sociedade.

Sem a pretensão de esgotar a matéria, a presente incursão no espectro da operação eleitoral de 2002 buscará a abordagem de tópicos que, ao longo deste

4. Qui Gouverne, trad. de Pierre Birman e Pierre Birnbaum, Paris, Librairie Armand Colin, 197I, p. I.

5. Reflexo do sistema eleitoral adotado no Brasil para as eleições para a Câmara dos Deputados e as Assembléias Legislativas, resultou a eleição dos representantes do PRONA, partido que, no pleito de 2002, por contar com um candidato contemplado com um grande número de votos, acabou por conquistar 6. cadeiras, sendo que todos estes candidatos beneficiados obtiveram de per si uma votação inócua, insuficiente para os conduzir à vitória. Mais que isto, passaram estes a ocupar assentos parlaınentares das quais outros candidatos, de outros partidos, com uma votação muito mais expressiva, foraın alijados. Ver sobre o tema o item 3.2, deste trabalho, versando sobre "Os Nanicos"

6. Os dados foram extraídos de reportagem da revista "Veja", edição de novembro/ 2002, tendo por fonte: TSE, consultoria GT Marketing e Comunicação e partidos. 
processo, foram objeto de discussões específicas ou que, por polêmicos, se impõem ao analista demandando-lhe peculiar atenção, a exemplo do perfil numérico do atual quadro partidário, alcançando o problema dos nanicos, a influência do direito de antena nas coligações realizadas, os aspectos, sempre inquietantes, do financiamento das campanhas eletivas e o sistema eleitoral empregado com os conseqüentes resultados.

Tratamento Legal. O Bloco Normativo.

A complexidade, da índole do processo eletivo por tendência natural, espalha o seu domínio para alcançar todo o espectro eleitoral, contagiando a própria legislação que, neste específico ambiente, se apresenta esparsa, sinuosa e afeta a constantes flutuações, sempre submissas à influência dos interesses do grupo detentor do poder político. Sob este aspecto, meritória a solução adotada pela Constituição Federal que, por via da Emenda Constitucional n. 4/1993, introduziu uma cláusula de bloqueio a alterações casuísticas, de última hora, e com pauta no princípio da anualidade, acabou desestimulando a produção de novas normas de regência do processo eleitoral, vedando a aplicação daquelas editadas no período de um ano antes da respectiva realização. ${ }^{7}$

Oportuno registrar que, já a partir de 1997, perseguindo-se a segurança jurídica, o processo eleitoral passou a ser disciplinado por um texto de cunho duradouro, ao menos editado com caráter permanente, diferentemente da técnica adotada no passado recente que descortinava para cada pleito eletivo um novo diploma legal a regulamentáIo. Assim, a Lei n. 9.504, de 30 de setembro de $1997^{\star}$. passou a dispor sobre o processo eleitoral, tanto em esfera nacional, em se tratando de eleições gerais, como, também, em cenário municipal, disciplinando os pleitos destinados à seleção de prefeitos e vereadores. A sua promulgação, de fato, configura forte indicador de aperfeiçoamento na linha evolutiva do quadro normativo incidente sobre a operação eleitoral, deixando para o escaninho da história a tradição de, a cada consulta, editar-se nova norma reguladora.

Não logrou este diploma, todavia, reduzir ou, até mesmo, simplificar o emaranhado de normas a comandar as eleições. Ao invés, a seu lado, continuam

7. Trata-se do art. 16 da C.F. com a seguinte redação: "A lei que alterar o processo eleitoral entrará em vigor na data de sua publicação, não se aplicando à eleição que ocorra até I (um) ano da data de sua vigência" gerais).

8. A primeira aplicação deste diploma deu-se com a realização da consulta popular de 1998 (eleições 
operando outros textos disciplinadores, instalando-se uma verdadeira rede normativa, uma "net" ou um bloco de legalidade eleitoral, o bloco normativo de regência das eleições, de irrefutável fertilidade.

Assim é que, o Código Eleitoral (Lei n. 4.737, de 15 de julho de 1965), remanesce com comando normativo sobre determinados tópicos, a exemplo de matéria versando registro de candidatura, (arts. 88, caput, 91, § 1", 94, etc.), convenções (art. $100, \S 2^{\circ}$ ), cédulas oficiais (art. 104), garantias eleitorais (arts. 235, 236, "caput" e $\S$ 1"), composição e trabalhos das juntas eleitorais, Mesas Receptoras, instalação da seção eleitoral (art. 142), votação (arts. 144 e ss). A Lei partidária (Lei n. 9.096, de 19 de setembro de 1995), a seu turno, traz importantes mecanismos de ação eleitoral, como também vedações, buscando amenizar as turbulências peculiares às campanhas, encontrando aplicação em vários segmentos do processo eleitoral, como o terreno das convenções. Mais ainda, o quadro de inelegibilidades, os prazos de desincompatibilização e o processo de impugnação ao registro das candidaturas vem estabelecidos no bojo da Lei complementar n. 64, de 18 de maio de 1990, texto que encontra por fundamento o disposto no $\S 9^{\prime \prime}$, do art. 14 da C.F. Ainda mais, a célebre Lei Etelvino Lins (Lei n. 6.091, de 15 de agosto de 1974), revelando-se, desde sua gênese, temido mecanismo destinado à moralização dos pleitos, uma arma de regular desempenho na luta contra $o$ aliciamento, exatamente por combater o transporte irregular de eleitores. ${ }^{9}$ Basta a mais breve incursão no texto deste diploma dos anos 70 para verificar como vários ainda são os dispositivos a comandar o processo eleitoral, expandindo-se para além do tema transporte de eleitores.

E mais até, o tema propaganda, abundantemente disciplinado pela Lei $n$. 9..504/ 97, continua, também, a atender a um comando do velho Código Eleitoral, a norma do art. 237, hoje concebida como verdadeiro princípio a obstaculizar a interferência do poder econômico na realização da consulta eletiva e suas nocivas irradiações sobre os resultados.

Irradiando sérios reflexos sobre o processo eleitoral e alinhando-se aos textos legais que incidem sobre o tema eleições, não há como ignorar o vasto elenco de resoluções baixadas pelo TSE, no exercício de sua competência normativa. A cada operação eleitoral, novas instruções são editadas por esta Justiça especializada, provocando um extraordinário inchaço do denominado bloco normativo de regência.

9. A Lei Etelvino Lins teve o mérito de inaugurar regra proibitiva (art. 13) quanto ao ingresso, dispensa, remoção e movimentação, em geral, de servidores públicos nos períodos eleitorais, situações, hoje, regidas pelo art. 73, V, da Lei n. 9.504/97. 
A título ilustrativo, vale lembrar as 16 (dezesseis) Resoluções ${ }^{10}$ a nortear o pleito/ 2002, suplementadas por, pelo menos, outras 22 (vinte e duas), quer na condição de modificativas, quer como supressivas ou, ainda, complementares.

É certo que a florescência deste complexo bloco normativo tem oferecido diliculdades ao aplicador da lci e ao seu intérprete, tornando o panorama eleitoral um inquictante e nevrálgico espaço a ser explorado. Certo é, também, que este clima se agrava diante dos arroubos da Justiça Eleitoral que, por intermédio do seu poder normativo, regulamentador, não raras vezes, se investe no papel de legislador para impor condutas não previstas na lei. Nessa trilha a tentativa de verticalização" das coligações partidárias, empreendida pelo TSE por intermédio da atacada Resolução n. 20.993/2002.

De fato, abandonando a razoabilidade do padrão adotado na edição das instruções anteriores, que não se distanciavam do texto legal (art. 6" "caput" da Lei n. 9.504/97) e facultavam aos partidos a confecção de alianças diferentes a nível nacional e estadual (porquanto cuida-se aqui de dois diferentes pleitos: um em esfera nacional e outro na dos Estados-membros da federação), o novo regulamento introduziu a figura da verticalização, inaugurando a obrigatoriedade de as coligações partidárias, em esfera estadual, acompanharem os acordos nacionais. Desde logo contestada esta limitação cm razão das distorções cleitorais que ensejaria, o lato não chegou a sensibilizar o Supremo Tribunal Federal que entendeu prejudicada a questão por versar sobre eventual "ilegalidade”, ou seja, a desconformidade da atacada instrução (um mero regulamento) à lei, não se enquadrando como tema de cunho constitucional. Evidenciou, contudo, que a matéria poderia vir a ser tratada no restrito âmbito do registro das candidaturas, reabrindo-se, em instância inferior, a sua discussão. ${ }^{12}$

10. Resoluções: 20.890 - Calendário Elcitoral, 20.950 - Instruções sobre Pesquisas Eleitorais, 20.95 ] - Reclamações e Representações, 20.986 - Número de Meınbros para a Câmara dos Deputados e as Assembléias Legislativas, 20.987 - Arrecadação e A plicação de Recursos, 20.988 - Propaganda Eleitoral e Condutas, 20.993 - Escolha e Registro dos Candidatos, 20.994 - Formulários Utilizados, 20.995 Cédulas Oficiais, 20.996 - Modelo e Uso dos Lacres, 20.997 - Alos Preparatórios, 20.998 - Justificativa dos Elcitores, 20.999 - Voto do Eleitor, $21.0(0)$ - Apuraçĩo dos Votos, $21 .(0) 8$ - Voto dos Eleitores Portadores de Defíciência, 21. 079 - revoga o art. $8^{\circ}$ e o $\$ 2^{\circ}$ Jo art. 15 da Resolução 20.993. Resoluções complementares: 21.084 - Instrução sobre atos preparatórios, 21.092 - Pesquisas eleitorais, 21.078 Propaganda partidária, 21.085 - Totalização de Votos, 21.106 - Registro de candidatura,conferência de fotografia e dados, 21.124 - Modelos de lacres e etiquetas, Instrução Norınativa Conjunta SRF/TSE n. 183, de 26.07.02 - controle da movimentação financeira dos fundos de campanha eleitoral, para coibir o uso indevido de recursos.

11. Ver o item 3.1 deste estudo.

12. Trataram da questão as Adin's n. 2628-3, proposta pelo PFL (Partido da Frente Liberal), e a de n. 2626-7, ajuizada pelos PC do B (Partido Comunista do Brasil), PL (Partido Liberal), PSB (Partido dos Trabalhadores Socialista Brasileiro) e PPS (Partido Popular Socialista). 
Releva registrar, no entanto, que o próprio TSE retrocedeu, acabando por suavizar a intensidade da restrição idealizada. Em abril de 2002, o Diário da Justiça, edição do dia 19, estampava as Resoluções de n. 21.045, de 26 de março de 2002, c a de n. 21.046, da mesma data, resultantes das Consultas, respectivamente de n. 758/DF e 759/DF, onde buscava apaziguar o clima de intranqüilidade instalado, assegurando: "Partidos políticos que não estejam disputando a eleição presidencial podem se unir a outros na mesma situação para disputar outras eleições" (item 6/ Res. 21.045) e proclamando: "Partidos políticos que não estejam disputando, isoladamente ou em coligação, a eleição presidencial podem celebrar coligações para disputar eleiçōes estaduais com partidos políticos que estejam, isoladamente ou em coligação, disputando a eleição presidencial" (item 2/ Res. 21.046).

De qualquer forma, fragilizada por força dos múltiplos ataques e, principalmente, pela atenuação que o próprio autor, o E. Tribunal Superior Eleitoral, Ihe outorgou, a figura da verticalização passou, de forma célere, para a coluna das meras ficções, deixando de produzir os efeitos desejados pelos idealizadores. De rigor, o quadro das coligações de 2002 oferece uma visão de acordos heterodoxos, carentes de coerência política e absolutamente distantes da perspectiva de fixar o caráter nacional dos partidos brasileiros para fortalece-los, como pretendia o seu defensor, Ministro Nelson Jobim do E. Tribunal Superior Eleitoral. Daí a presença de acordos inéditos e altamente surpreendentes, a exemplo da coligação do PL com o PT a nível nacional c com o PPB no Estado de São Paulo, c o PMDB concluindo, no Estado do Maranhão, coligação com o PSDB c o PFL cm âmbito estadual c, mediante entendimentos de apoio, com o PT para a eleição presidencial.

Outro impacto sobre o quadro legal a disciplinar a operação eleitoral/ 2002, resultou de decisão liminar proferida pelo E. Supremo Tribunal Federal, em Adin. ${ }^{13}$ ajuizada pelo Procurador Geral da República, atacando o disposto no $\$ 1$ " do art. 8" da mencionada Lei n. 9.504/97, que outorgava aos atuais parlamentares a condição de candidatos natos pela respectiva legenda, assegurando-lhes, portanto, a possibilidade de disputar posto eletivo, para fins de reeleição, sem prévia submissão à Convenção do respectivo partido. Por força do pronunciamento do Excelso Pretório, liminarmente, suspendeu-se a aplicação do dispositivo - (que produziu plenos efeitos nas eleições de 1998) - por entenderem, (8) oito dos (9) nove integrantes do Tribunal presentes,

13. Ação Direta de Inconstitucionalidade n. 2.350. A decisão do STF nulificou a regra da “ candidatıı a nata" que assegurava aos parlamentares legenda partidária para a reeleição, não os obrigando a subınctcr previamente a candidatura à apreciação e deliberação do órgão máxiıno partidário, a Convenção. 
que a norma encontrava-se inquinada de inconstitucionalidade, violando a autonomia partidária, ou seja, a liberdade de, por via estatutária, cada um dos partidos vir a normatizar a questão da candidatura nata, com vista a critérios próprios de oportunidade c conveniência.

\section{O Quadro Partidário}

Sob permanentes e orquestrados ataques por hospedar um número superlativo de agremiações político-partidárias, derivado de um processo de célere prolilicração que acompanhou o clima de redemocratização do país e, por que não admitir, reflexo da própria mecânica adotada para a composição das Casas Legislativas - i.é, a técnica proporcional - o sistema de partidos praticado no panorama doméstico vem, todavia, se firmando, apesar do quadro que é descortinando: um quadro pluriparlidário, de considerável pulverização. Hoje, mister reconhecer que referido sistema logrou atingir, de alguma forma, um determinado nível de amadurecimento e equilíbrio, embora, ainda, se detecte a presença de elementos de desvio, a exemplo dos denominados "nanicos", convivendo com os grandes e potentes partidos no complexo universo político. Mais ainda, a Lei n. 9.096, de 19 de setembro de 1995, que introduziu medidas rígidas e requisitos de difícil consecução para a criação de novas organizações, concorreu de modo especial para a estabilização do quadro que, já desde 1999, vem atuando com 30 (trinta) partidos detentores de registro junto à Justiça Eleitoral. ${ }^{14}$ Aliás, a perspectiva de estabilidade já era visualizada por Cláudio Lembo ao anotar: " $E$ plausivel admitir que, findo o processo de redemocratização, os partidos políticos conseqüentes tornar-se-ão atores estáveis, contando com arcabouços bem elaborados $e$, assim, democraticamente atuantes, poderão se converter em agentes de efetiva participação dentro do Sistema de Partidos. "15

Oportuno reiterar, a esse passo, a célebre observação lançada por

14. Desde 1979, inarco de retorno ao pluripartidarismo, e ao longo destes 24 anos de história, o quadro partidário, no Brasil, vem tiınbrado por intensa flutuação, resultante, de fato, de um processo de proliferação que é natural ao momento de redemocratização e abertura política. A florescência de partidos, dos mais variados quanto à cor política, ideologia e grandeza, passou a ser considerada como um dos caracteres de identificação do espectro de partidos em território brasileiro, que chegou a contar com cerca de 130 agremiaçōes. Nesse período, no entanto, 53 partidos foram extintos e 34 séquer lograram o registro provisório junto à Justiça Eleitoral. O último momento deste período de explosão partidária posiciona-se no ano de 1989, quando, diante do movimento dos grandes partidos no sentido de impedir o ingresso de novos "nanicos", presenciou-se ao registro de 22 siglas. 70.

15. "Participação Política e Assistência Simples" Rio de Janeiro, Forense Universitária, 1991, p. 
Loewenstein, ${ }^{16}$ no sentido de que o Estado contemporâneo assume a configuração de um Estado de Partidos, donde emerge a figura da agremiação partidária na condição de detentora do monopólio do sistema eleitoral. Em verdade, no mundo atual, assume o partido posição fortalecida, de mecanismo de comunicação e de participação do processo decisional; mais até, de instrumento destinado ao recrutamento dos governantes e à socialização política. Diante, pois, de tal envergadura, importa perquirir acerca do tratamento apto a habilita-lo ao cumprimento dessa missão. E, conquanto, o ideal seja o atingimento da figura do "partido pasteurizado", construída por Manoel Gonçalves Ferreira Filho ${ }^{17}$, a complexidade do campo de competição pelo poder exige o desenho de um sistema de partidos aclimatado às nuanças e especificidades de cada comunidade política e ao tipo de representação política que pretende instalar.

Pois bem, a paisagem doméstica espelha acentuadas dificuldades no tratamento do território partidário, cláramente identificadas na mais breve incursão no scu traçado. Nesta perspectiva, merece registro desde logo o modelo eleitoral acolhido pclos constituintes, inspirados na tendência atual de priorização do fenômeno partidário, o que acabou por determinar a vinculação das candidaturas a partidos políticos, ${ }^{1 \times}$ inviabilizando a presença de candidatos independentes. Peça imprescindível, pois, no âmbito da operação eleitoral, ou seja, para a escolha dos governantes/representantes, o exame da figura partidária emerge impositivo, porquanto é por intermédio desse ente que as candidaturas são lançadas. Ademais, passa o partido, isoladamente ou, ainda, por via de coligação, a ser o responsável pelo registro dos candidatos que apresenta para a disputa dos votos e pelo desenvolvimento da campanha de divulgação a respaldar os seus postulantes.

Embora prestigiado o partido, sob o domínio da Lei n. 9.504/97, restou cnfraquecido o vínculo de solidariedade entre candidato e partido, no que concerne à realização da campanha eleitoral. Diferentemente do tratamento outorgado pelo legislador no passado - concentrando a responsabilidade na figura do partido - hoje essa encontra-se diluída, sendo liberado o candidato a administrar, por si, sua campanha, inclusive sob o aspecto financeiro (art. 20 da Lei n. 9.504/97) e a este sendo atribuída

16. Karl Loewenstein, “Teoria de La Comstitución”, Barcelona, Ed. Ariel, 1976.

17. Manoel Gonçalves Ferreira Filho, em obra publicada em 1977, define o modelo pasteurizado como "o partido de estrutura democrática, escolhidos pelas bases seus dirigentes, limpo de corrupção, com fontes puras de financiamento, de atuação perınanente, contribuindo para a formação política do povo" - "Sete Vezes Democracia", São Paulo, Ed. Convívio, 1977.

18. Conforme disposto no art. 14, $\$ 30$, inciso V, da Constituição Federal. 
a responsabilidade pela prestação de contas (art. $28, \S 2^{\circ}$ da Lei n. 9.504/97), regra que esbarra numa exceção: as eleições majoritárias (presidente, governadores e senadores), onde se mantém a cargo dos comitês financeiros, instalados pelos partidos, o dever de prestar as contas relativás à campanha empreendida (art. 28, § 1 " da Lei n. 9.504/97).

Nos períodos pré-eleitorais, dúvida não há, o partido conquista uma significativa, embora efêmera, sobrepujança. Isto porque, a par do domínio que detém sobre as candidaturas, que the foram asseguradas em regime de monopólio, foi ao partido, ainda, atribuída exclusividade no tocante às campanhas publicitárias pela rádio, ıclevisão e na distribuição dos "outdoors"' Aliás, o comando das campanhas por intermédio da mídia e o tempo de antena ${ }^{20}$, sobre o qual detém domínio absoluto, são fatores que concorrem de forma especial para a concretização das coligações, muitas vezes direcionadas a atender interesses da cúpula partidária, distanciando-se da perspectiva das bases.

Sob este particular aspecto, não há como se abster do registro de que as agremiações de menor expressividade eleitoral ingressam na disputa basicamente por via de coligações, com o objetivo, via de regra, de concorrer para a ampliação do tempo de antena dos mais poderosos, conquistando, em contrapartida, recursos de marketing e espaço mais promissor para os seus próprios candidatos. Por vezes, porém, sua participação tem por escopo mero ato de presença eleitoral, presença que, quando não produz efeitos nocivos sobre a campanha, por privilegiar, a partir da penumbra, candidato de maior potencial, é salutar para o robustecimento da participação política e ampliação das possibilidades de exercício da cidadania.

\section{As Coligações}

O momento eleitoral, revelado por força da radiografia do pleito de 2002, não se apresenta diferente quanto a esta peculiar faceta. Inobstante a inserção da figura da verticalização, rapidamente absorvida pelo sistema que, em pouco tempo, lhe neutralizou os efeitos, ${ }^{21}$ foi dado observar uma avalanche das mais esdrúxulas coalizões,

19. No que toca à partilha dos espaços para a afixação de propaganda por "outdoors" ver o art. 43 da Lei 9.504/97. Em relação à publicidade por via de rádio e t.v. consultar os arts. 44 a 57 do mesmo texto.

20. A questão aqui tratada diz respeito ao tempo de cada partido no horário gratuito de propaganda eleitoral no rádio e na televisão. A partilha, nos moldes preconizados pelo legislador, sofre forte influência da representação de que dispõe cada agremiação junto à Câmara dos Deputados. As coligações, notadamente para os pleitos majoritários, sofrem o reflexo da necessidade de ampliação desse tempo de antena, poderoso veículo de marketing político-eleitoral.

21 . Ver a respeito o item 2 deste trabalho. 
na busca, especialmente, da ampliação do tempo de exposição na mídia. Resultado direto desta necessidade, vem assinaladas as já referidas alianças do PL com o PT, de Lula, para a campanha presidencial e com o PPB, de Paulo Maluf, em São Paulo. De qualquer forma, a partir dos acordos consagrados a nível nacional, infra-arrolados, exsurge evidente a nebulosidade e a heterodoxia que passou a insuflar as coligações em esfera estadual, descortinando, afinal, um quadro caótico em termos de linha, programa e ideologia políticas.

Neste cenário, para a presidência foram registradas 6 (seis) chapas, das quais 4 (quatro) traziam na liderança candidaturas suportadas por partidos de destaque c 2 (duas) representavam os denominados nanicos. ${ }^{22}$ Em âmbito estadual, as 27 cadeiras de governador foram disputadas por 116 candidatos, apoiados, oficial ou informalmente, pelos mais diversos partidos. Assim, o PT, por cxemplo, estabeleceu as mais variadas alianças em esfera estadual: no Acre, lançou candidato em coligação com o PC do B, PMN, PV, PT do B, PSDC e informalmente com o PSB; no Amapá, com PC do B, PMN, PV, PGT, PHS, PST, PAN, PSC (aqui o PL apoiou a candidatura do PSDB), no Rio de Janeiro, com PC do B e PMN (o PL apoiou, informalmente, Rosinha Mateus PSB), no Sergipe, com PC do B, PMN, PLe, informalmente, com PSB, no Mato Grosso do Sul, com PC do B, PL e, informalmente, com PDT e PPS, em Minas Gerais, com PC do B, PMN, PL e PCB, no Ceará, com PC do B, PCB e PL. Não muito distante do esquema de suporte de candidaturas organizado pelo PT, o PSDB (até l" de janeiro de 2003: partido governista) estabeleceu acordos: no Amapá, com PMDB, PPB e, informalmente com o PL, no Acre, não apresentou candidato, apoiando o postulante do PMDB, juntamente com o PFL, PPB e PSL, no Rio de Janeiro, também não apresentou candidatura própria, apoiando em coligação o candidato do PFL, com o PMDB e o PPB, no Sergipe, coligação com o PMDB e PPB, em Mato Grosso do Sul, com PMDB, PFL e, informalmente, com o PTB, em Minas Gerais, com PFL, PPB e, informalmente, com o PPS, PDT, PTB e PMDB, no Ceará, com PPB e, informalmente, com PPS. Em síntese, o PSDB e o PMDB fecharam coligações em dez dos Estados brasileiros; o PT e o PL formaram coligação em nove dos Estados. Em ambos os casos, contaram com o ingresso de outras legendas. ${ }^{23}$

22. Candidatos à Presidência da República/ Eleições 2002: Anthony Garotinho (PSB - seın coligação), Ciro Gounes (PPS + PDT + PTB), José Serra (PSDB + PMDB), Luiz Inácio Lula da Silva (PT + PL) e os "nonicos": José Maria (PSTU) e Rui Costa Pimenta (PCO - Partido da Causa Operária). 
Os Nanicos

Um dos pontos de maior polêmica a envolver o sistema de partidos no Brasil reside na convivência de grandes e poderosas agremiações com outras de reduzida expressão política e duvidosa densidade cleitoral, porém de amplo poder de ingerência no processo político eleitoral,-por se posicionarem no papel do "fiel da balança" e, conseqüentemente, de indispensável presença na formação de maiorias parlamentares ${ }^{24} \mathrm{ou}$, ainda, na formação de coligações, ou, ainda, no campo do apoiamento informal que oferecem no decurso das campanhas políticas, atuando de forma camuflada a favor ou contra determinado candidato, porém a partir dos bastidores.

A trajetória histórica, de fato, vem revelando uma postura estacionária destas organizações - os nanicos - que, na sua maioria, não conseguem um grau de representatividade desejado, conquistando bancadas parlamentares. Com poucas exceções - como se constata da mera visualização do quadro (1) abaixo apresentado estes partidos permanecem em cena política como legendas de aluguel, instrumentos de campanha para as agremiações mais robustas c, de forma geral, produzindo efeitos poluentes, nocivos ao clima clcitoral.

Alguns, muito poucos, avançaram. É o caso do PC do B, do PRONA, do PSD, do PST e do PV. O fenômeno desenvolvimentista, contudo, não pode ser atribuído ao crescimento efetivo do grau de densidade representativa do partido. As eleições de 2002 demonstraram uma séric de distorções sob este aspecto. Os partidos que apoiaran o PT - o partido do grande vencedor deste pleito, o presidente Luiz Inácio Lula da Silva - vieram a ser beneficiados com a vitória, conquistando um espaço parlamentar maior ${ }^{25}$. Quanto ao PRONA, advertem os analistas políticos quanto ao voto de protesto que acabou favorecendo o seu líder maior, o médico Enéas Ferreira Carneiro, contemplado com 1.573 .642 votos, o que acabou favorecendo a legenda, redundando na conquista de outras 5 cadeiras parlamentares, outorgando-se mandato parlamentar a candidatos de ínfima votação. ${ }^{26}$

24. Ver a respeito as notas ao Quadro 2.2, constante deste estudo.

25. Ver a respeito as notas ao Quadro 2.2, constante deste estudo

26. Com base na votação obtida por Enćas foram eleitos: Amauri Robledo Gasques ( 8.42 I votos); Vanderlei Assis de Souza (275 votos); Ildeu Alves de Araújo (382 votos); Elimar Máximo Damasceno (484 votos); e Irapuan Teixeira (673 votos). O caso PRONA vem discutido no item 5 do presente artigo. 
Quadro (1)

Os Nanicos Nas Eleições/2002

\begin{tabular}{|c|c|c|c|}
\hline Partido & $\begin{array}{l}\text { Cadeiras } \\
\text { em } 1998\end{array}$ & $\begin{array}{l}\text { Cadeiras } \\
\text { em } 2002\end{array}$ & $\begin{array}{c}\% \text { votos obtida } \\
\text { em } 2002\end{array}$ \\
\hline $\begin{array}{c}\text { PAN-Partido dos Aposentados } \\
\text { da Nação }\end{array}$ & 0 & 0 & 0,0941 \\
\hline $\begin{array}{c}\text { PCB-Partido Comunista } \\
\text { Brasileiro } \\
\end{array}$ & 0 & 0 & 0,0745 \\
\hline $\begin{array}{c}\text { PC do B-Partido Commenista do } \\
\text { Brasil }\end{array}$ & 7 & 12 & 1,3052 \\
\hline PCO-Partido da Causa Operíria & 0 & 0 & 0,0121 \\
\hline $\begin{array}{l}\text { PGT: Partido Geral dos } \\
\text { Traballhadores }\end{array}$ & 0 & 0 & 0,0418 \\
\hline $\begin{array}{c}\text { PMN-Partido da Mobilizaşão } \\
\text { Nacional }\end{array}$ & 2 & 1 & 0,5409 \\
\hline $\begin{array}{c}\text { PRONA-Partido de Reedifiscão da } \\
\text { Ordem Nacional } \\
\end{array}$ & 1 & 6 & 0,8898 \\
\hline $\begin{array}{c}\text { PRP. Partido Republicano } \\
\text { Progressista }\end{array}$ & 0 & 0 & 0,3837 \\
\hline $\begin{array}{c}\text { PRTB-Partido Renovador } \\
\text { Trabalhista Brasileiro }\end{array}$ & 0 & 0 & 0,0808 \\
\hline PSC-Partido Social Cristāo & 2 & 1 & 0,6702 \\
\hline PSD-Parrido Social Democrático & 3 & 4 & 0,7563 \\
\hline $\begin{array}{c}\text { PSDC- Partido Social Democrata } \\
\text { Cristūo (ex-PDC) }\end{array}$ & 0 & 1 & 0,0932 \\
\hline PSL- Partido Social Liberal & 1 & 1 & 0,2658 \\
\hline PST-Partido Social Trabalhista & () & 3 & 0.2906 \\
\hline $\begin{array}{l}\text { PSTU-Partido Socialista dos } \\
\text { Trabalhadores Unificado }\end{array}$ & 0 & 0 & 0,2818 \\
\hline $\begin{array}{c}\text { PT do B - Partido Trabalhista do } \\
\text { Brasil }\end{array}$ & 0 & 0 & 0,3253 \\
\hline PTN-Partido Trabalhista Nacional & 0 & 0 & 0,0972 \\
\hline PV-Partido Verde & 1 & 5 & 0,4395 \\
\hline
\end{tabular}

Convém lembrar que esta problemática, a envolver a presença das pequenas formações partidárias, já foi objeto de remodelação por força do advento da Lei n. 9.096, de 19 de setembro de 1995. O seu art. 13 introduz a temida cláusula de bloqueio que só admite funcionamento parlamentar (bancadas) para os partidos que alcancem, nas eleições para a Câmara dos Deputados, 5\% dos votos apurados, distribuídos em, pelo menos, 9 Estados, com um mínimo de $2 \%$ de votos em cada um deles. Embora esta regra tenha sido abrandada, com vistas a admitir um período de acomodações, certo é que, a partir da proclamação dos resultados das eleições de 2006, a la terá plena aplicabilidade, agravando as condições de sobrevivência dos "nanicos"; isto na hipótese da não intercorrência de novas remodelações. 
E mais até, há uma série de medidas, tramitando no Congresso, buscando introduzir institutos que possam oferecer maior equilíbrio ao sistema, a exemplo de projeto de lei direcionado a acolher, entre nós, o partido regional, proposta inspirada em modelos cxtraídos de democracias consolidadas como a norte-americana, a inglesa, etc.

\section{A Dança das Cadeiras}

A Fidelidade Partidária

Um dos pontos de maior inquietação desta engenharia partidária é revelado pela ausência total de regras cogentes em matéria de fidelidade. Pretendeu, de fato, o constituinte de 1988 assegurar robustez ao sistema de partidos, criando esta ligadura insuperável com as candidaturas e, portanto, garantindo aos partidos domínio absoluto sobre toda a operação eleitoral. Muito distante das perspeclivas de regulação adequada a melhor lapidá-lo, capacitando-o para servir de base sólida ao desenvolvimento da democracia, não houve, porém, qualquer preocupação com detcrminadas facetas, extremạmente sensíveis, da questão partidária, desprezando-se temas relevantes para o fortalecimento dos partidos, a exemplo da vinculação dos filiados, candidatos, à ideologia, ao programa, enfim às propostas e projetos políticos das agremiações. É deste quadro, identificado pela carência de um disciplinamento constitucional adequado e, essencialmente, pela fragilidade e plasticidade dos partidos brasileiros que emerge o movimento de turismo interpartidário ou a "Dança das Cadeiras". como passa a ser conhecido na mídia.

Forçoso convir que a idéia Estado de Partidos, ${ }^{27}$ que se infiltra e permeia a construção de um tipo especial de democracia - a operacionalizada por via dos partidos - impacta o cenário eleitoral, compelindo o eleitor a uma verdadeira opção por programas e plataformas governamentais oferecidos pelas agremiações; como reflexo, ao candidato vitorioso impõe-se o dever de respeitar e atender essas coordenadas partidárias, sob pena de vir a ser destituído por infidelidade, porquanto, assim, assegurar-se-á a necessária credibilidade às propostas políticas de campanha, possibilitando que, a qualquer momento, o suplente, assumindo, venha a garantir o cumprimento das idéias defendidas no momento pré - eleitoral e que serviram de base à vitória.

27. Cf. o nosso Finanças Partidcírias, Brasília, Editora do Senado Federal, 1983. Ver, ainda, Leibholz, Gerard, Friedrich, Carl J. e Karl Loewenstein que afirma: "A teoria constitucional européia e iberoamericana tem plena consciência do fato de que o Estado do século $X X$ é um Estado de Partidos (parteienstaat) e de que a posiçio da soberania popular foi ocupada praticamente pela soberania dos partidos". - Teoria de La Constitución, Barcelona, Ed. Ariẹl, 1976, p. 45I (tradução do espanhol nossa). 
A tônica da fidelidade partidária e a viabilização da perda do mandato por desrespeito às diretrizes e propostas que serviram de superfície à opção promovida pclo elcitor, ganha, neste ambiente, terreno fértil. O modelo acolhido pelo atual Estatuto Fundamental, todavia, não autoriza laços sensíveis entre o eleito e o partido sob cuja legenda concorreu, conquistando a cadeira parlamentar. Desenha o perfil do congressista desvinculado de interesses parciais, de regiões ou circunscrições - redutos eleitorais. $O$ art. 45 da Constituição parece-nos inequívoco nesse sentido, ao contemplar o deputado federal com uma verdadeira missão - missão constitucional - a de representar os interesses do povo, ou seja da coletividade política do Estado, in verbis:

"Art. 45. A Câmara dos Deputados compõe-se de representantes do povo, eleitos, pelo sistema proporcional....."

O eleitorado, pois, comparece com o seu perfil de eleitorado função ${ }^{2 \mathrm{x}} \mathrm{e}$, daí, difícil a introdução de regras mais rígidas a punir a infidelidade, inclusive com a perda do mandato parlamentar, apesar do esforço legislativo que vem sendo cmpreendido, numa linha de moralização e dos significativos projetos de reforma nessa linha apresentados.

Destarte, conquanto no campo das candidaturas avulte, com intensidade, a obrigatoriedade de filiação partidária, erigida mesmo à condição de elegibilidade, $e x$ vi da norma, já acima referida, do inciso $\mathrm{V}$, do $\$ 3^{\prime \prime}$, do art. 14, da Lei Fundamental, demonstrando a intenção de fortalecer o sistema partidário, erigindo-o a relevante peça da cena eleitoral, ao outorgar ao parlamentar a missão de representar o povo, o constituinte o liberou da ligadura com o partido, abrindo a brecha para a continuidade do esquema de turismo interpartidário, que retira todo o equilíbrio ao quadro de partidos c ao sistema que os constituintes pretendiam engendrar.

O tema passa a demandar a atenção da doutrina especializada, dos políticos e dos cientistas políticos a partir do paradoxal disciplinamento constitucional que, de uma parte, cometeu à figura do partido o monopólio das candidaturas e, de

28. Clássicas as lições que nos posicionam quer diante de uma configuração de eleitorado função sede na qual ao Estado compete definir os parâmetros a disciplinar a tarefa cometida aos cidadãos, qual seja de escolherem os representantes encarregados de adotar as decisões políticas; delinea-se, nesse escaninho, o mandato representativo típico, ausentes quaisquer vínculos com o colégio eleitoral que elegeu o parlamentar e o sufrágio é erigido a dever de cidadania. De outro lado, situa-se a idéia do eleitorado direito, a servir de superfície ao inodelo do voto facultativo, porquanto, nessa configuração, assegura-se ao cidadāo/eleitor uma opção quanto a exercer ou não o direito de sufrágio. Ver sobre a matéria o nosso Sistemas Eleitorais X Representação Política, Brasília, Senado Federal, 1991. 
outra, contemplou o representante cleito com a tarefa de representar o povo, atribuindo, ainda, à agremiação partidária a condição de mera associação de natureza privada ${ }^{29}$ (art. 17, "caput") e a autorizou a cuidar da questão da infïdelidade partidária, a nível cstatutário (\$ 1"., art. 17, C.F.), a partir, portanto, de regras de cogência duvidosa. Deu enscjo, destarte, a um quadro de instabilidade a dominar o território doméstico, facilmente aprecndido a partir dos demonstrativos abaixo, que descortinam um espeláculo todo peculiar a envolver um movimento de mudança de partido $\mathrm{cm}$ razão do processo eleitoral, às vésperas de uma cleição: in cası, as últimas elciçõos gerais de 1998 e de 2002:

Quadro (2)

21. Dança das Cadciras

(legislatura 1999 a 2003/ sct.de 200I)

\begin{tabular}{|c|c|c|c|c|}
\hline Parlido & $A$ & $B$ & $C$ & $D$ \\
\hline $\mathrm{PFL}$ & 89 & 112 & 106 & $\begin{array}{r}3 / 10 / 2001-95 \\
31 / 12 / 2002-94 \\
\end{array}$ \\
\hline PSDB & 62 & 94 & 99 & $\begin{array}{r}3 / 10 / 2001-94 \\
31 / 12 / 2002-93 \\
\end{array}$ \\
\hline PMDB & 107 & 84 & 82 & $\begin{array}{r}3 / 10 / 2001-87 \\
31 / 12 / 2002-85 \\
\end{array}$ \\
\hline $\mathrm{PPB}$ & & 78 & 60 & $\begin{array}{r}3 / 10 / 200|-5| \\
3|/| 2 / 2002-54 \\
\end{array}$ \\
\hline PT & 49 & 50 & 57 & $\begin{array}{r}3 / 10 / 2001-50 \\
31 / / 2 / 2002-573 / \\
\end{array}$ \\
\hline PDT & 34 & 24 & 25 & $\begin{array}{rr}10 / 2001 & 18 \\
3|/| 2 / 2002 & -16 \\
\end{array}$ \\
\hline PTB & 31 & 22 & 30 & $\begin{array}{r}3 / 10 / 2001-33 \\
31 / 12 / 2002-34 \\
\end{array}$ \\
\hline PSB & 15 & 14 & 19 & $\begin{array}{rr}3 / 10 / 2001 & 16 \\
31 / 12 / 2002 & -16 \\
\end{array}$ \\
\hline $\mathrm{PL}$ & 13 & 09 & 11 & $\begin{array}{rr}3 / 10 / 2001 & 23 \\
31 / 1 / 2 / 2002 & -23 \\
\end{array}$ \\
\hline PC do B & 10 & 09 & 07 & $\begin{array}{rr}3 / 10 / 2001 & 10 \\
31 / 12 / 2002 & -10 \\
\end{array}$ \\
\hline PMN & 04 & 01 & 02 & $-x-$ \\
\hline PSD & 03 & 03 & 03 & $-x-$ \\
\hline PSC & 03 & 0 & 02 & $-x-$ \\
\hline PPS & 02 & 07 & 03 & $\begin{array}{rr}3 / 10 / 2001 & 13 \\
31 / 12 / 2002 & -11 \\
\end{array}$ \\
\hline PRN & 01 & 0 & 0 & $-x-$ \\
\hline
\end{tabular}

29. Sob a anterior ordem jurídica, os partidos políticos eram considerados pessoas jurídicas de direito público interno, nos termos definidos pela LOPP eın vigor à época. 


\begin{tabular}{|c|c|c|c|c|}
\hline PV & 01 & 01 & 01 & $\begin{array}{c}3 / 10 / 2001 \\
31 / 12 / 2002-0 \\
\end{array}$ \\
\hline PRP & 01 & 0 & 0 & $-x-$ \\
\hline PSL & 0 & 02 & 01 & $\begin{array}{r}3 / 10 / 2001-5 \\
31 / 12 / 2002-5\end{array}$ \\
\hline PST & & & 01 & $\begin{array}{r}3 / 10 / 2001-4 \\
31 / 12 / 2002-6\end{array}$ \\
\hline PTN & & & 0 & $\begin{aligned} 3 / 10 / 2001 \\
31 / 12 / 2002-1\end{aligned}$ \\
\hline PRONA & 0 & 01 & 01 & $-x-$ \\
\hline PSTU & 0 & 01 & 0 & $-x-$ \\
\hline PHS & & & 0 & \begin{tabular}{rl|}
$3 / 10 / 2001$ \\
$31 / 12 / 2002-1$
\end{tabular} \\
\hline PSDC & & & 0 & $\begin{array}{rr}3 / 10 / 2001 & 1 \\
3 / / 12 / 2002 & -0 \\
\end{array}$ \\
\hline Sem partido & & & & $\begin{array}{cc}3 / 10 / 2001 \\
31 / 12 / 2002 & -7\end{array}$ \\
\hline Total & & & & 513 \\
\hline
\end{tabular}

Na tabela:

A: Cadeiras em 01/02/96 (legislatura 1996 a 1999).

B: Caldeiras em 10/97 (preparo para as eleições/98).

C: Resultado cleitoral de 1998 (cadeiras conquistadas).

D: Cadeiras em 03// 0/2001 (para disputar o pleito de 2002);

e cm 31/12/2002 (ainda a composição da legislatura 1999-2003, após os resultados eleitorais.

\subsection{Dança das Cadeiras}

(eleişoses/2002 - legislatura 2003/2007)

\begin{tabular}{|c|c|c|c|}
\hline Parlido & A & B & C \\
\hline PFL & $31 / 12 / 2002-94$ & 84 & 77 \\
\hline PSDB & $31 / 12 / 2002-93$ & 70 & 63 \\
\hline PMDB & $31 / 12 / 2002-85$ & 75 & 70 \\
\hline PPB & $31 / 12 / 2002-54$ & 49 & 43 \\
\hline PT & $31 / 12 / 2002-57$ & 91 & 91 \\
\hline PDT & $31 / 12 / 2002-16$ & 21 & 18 \\
\hline PTB & $31 / 12 / 2002-34$ & 30 & 41 \\
\hline PSB & $31 / 12 / 2002-16$ & 22 & 28 \\
\hline PL & $31 / 12 / 2002-23$ & 26 & 34 \\
\hline PC (lo B & $31 / 12 / 2002-10$ & 12 & 12 \\
\hline PMN & & 1 & 2 \\
\hline PSD & & 1 & 1 \\
\hline PSC & & 15 & 19 \\
\hline PPS & $31 / 12 / 2002-11$ & & \\
\hline PRN & & & \\
\hline
\end{tabular}




\begin{tabular}{|c|c|c|c|}
\hline PV & $31 / 12 / 2002-0$ & 5 & 6 \\
\hline PRP & & 1 & 2 \\
\hline PSL & $31 / 12 / 2002-5$ & 3 & 0 \\
\hline PST & $31 / 12 / 2002-6$ & 6 & 6 \\
\hline PTN & $31 / 12 / 2002-1$ & & 0 \\
\hline PRONA & & 1 & 513 \\
\hline PSTU & & & \\
\hline PHS & $31 / 12 / 2002-1$ & & \\
\hline PSDC & & & \\
\hline TOTAL & & & \\
\hline
\end{tabular}

Na tabela:

A: Cadeiras ao final da legislatura 1999-2003

B: Resultado eleitoral de 2002 (cadeiras conquistadas)

C: Cadciras em 17.02.2003

1) Partidos que mais ganharam parlamentares e, portanto, cadeiras: PTB, PSB, PLe PPS (partidos que atuaram coligados com o PT e que integram, hoje, o bloco de sustentação do Governo). Assim, é interessante notar que o movimento migratório dos parlamentares não foi direcionado diretamente para o partido situacionista (PT); em busca das benesses governistas, os congressistas foram se acomodar junto a partidos, de médio e pequeno porte, que servirão de apoio ao governo Luiz Inácio Lula da Silva.

2) Partidos que mais perderam parlamentares e cadeiras: PFL(7), PSDB (7), PMDB (5), $P P B(6)$.

3) Total de parlamentares que, eleitos por uma legenda, mudaram de partido no início da legislatura:

4) Base aliada governista:PMDB (70), PL (34), PTB (41), PSB (28), PDT (18), PPS (19), $P C$ do $B($ I2) deputados $=222$ deputados $+P T(9 I)=313$ deputados.

5) Oposição: PFL (77), PSDB - de oposição suave e talvez tímida por vezes (63), PPB, oposição duvidosa (43).

6) Partidos que fizeram oposição ao Governo Fernando Henrique Cardoso ampliaram a sua base eleitoral. Como exceção a esta realidade, o PDT de Leonel Brizola.

Dessume-se, pois, inocorrer qualquer respeito, até mesmo, em relação à opção partidária manifestada pelo clcitor e expressa por via do voto. Este, de sua parte, parece encontrar-se plenamente consciente da fragilidade da tradição partidária e, em geral, promove sua escolha em favor do candidato e não do partido. E mais, realiza a sua apreciação quanto ao desempenho do seu candidato, individualmente, 
independentemente de qualquer postura do partido. Mais, ainda, o acompanha para qualquer partido a que esse venha a ingressar, como, também, não o surpreende a hipótese de esse restar, por um tempo - que pode corresponder à toda uma legislatura sem partido, numa atuação independente.

Não nos parece ter sido esse quadro o almejado pelos constituintes. Ao invés, a idéia prevalecente era a de reorganizar o sistema de partidos, assegurando à agremiação condições de bem cumprir o papel que lhe é atribuído em ambientes democráticos, como relatado, mais adiante, no tópico partidário.

Reflexo desse descompasso, a série de proposituras legislativas direcionadas à revalorização da agremiação político-partidária, a exemplo dos Projetos de Emenda Constitucional de n. 41/96, 50/96, 137/95, 90/95, 60/95, 51/95, 42/95, 85/ $95,166 / 95,283 / 95$, cada um deles, por intermédio de técnicas diferentes, buscando sancionar a conduta infiel, ou por via da perda do mandato parlamentar ou, ainda, erigindo o abandono do partido a mais uma hipótese de inelegibilidade, obstativa da candidatura por um período de dois anos (PEC n. 41/96 e 166/95).

Todas essas medidas reformulatórias integram o bloco do que se convencionou etiquetar como Reforma Político-Partidária, iniciando sua trajetória legislativa logo no começo da legislatura 1995/1999. Do bojo dessas reformas ${ }^{30}$, sagrouse vitoriosa tão só a reeleição, todas as demais destinadas a reiniciar sua caminhada; ao menos, essa é a expectativa.

\section{A Reeleição}

O tema traz a lume a sensível problemática da elegibilidade, que, a rigor, a todos pertence, a todos os que têm o direito de votar, assumindo o perfil de direito fundamental. Notadamente, em climas democráticos, a elegibilidade deve pender para a universalidade. Porém, há sempre possibilidade de inserção de determinados lindes, reduzindo-se o acesso a cargos eletivos e introduzindo-se a figura da inelegibilidade, nas suas variadas e diversificadas modalidades.

Certo é, no entanto, que a idéia de inelegibilidade penetra em cenário político e jurídico com o perfil de evidente excepcionalidade, porquanto implica numa

30. Integram o bloco das "Reformas Político-Partidárias" temas relativos a: sistema eleitoral; fidelidade partidária; desempenho eleitoral para conceito de partido nacional; cláusula de barreira; coligações partidárias; domicílio eleitoral e filiação partidária; financiamento das campanhas; reeleição dos titulares de cargos executivos; duração do mandato dos senadores e suplentes de senador; voto obrigatório e facultativo; segundo turno; divulgação de pesquisas eleitorais; imunidade parlaınentar; número máximo e mínimo de vereadores. 
restrição, obscurecendo, temporariamente, o espectro da elegibilidade, erigida a "liberdade pública fundamental" $\quad$ E, atento a esse peculiar perfil restritivo da figura da inelegibilidade, o nosso Texto Político estampa as linhas mestras a comandar a área, preordenando as limitações pela exigência de: domicílio eleitoral, filiação partidária e atribuindo ao legislador complementar ${ }^{32}$ a tarefa de detalhamento das diversas hipóteses da categoria das inelegibilidades proteção, ou seja, um elenco definido a partir de um sentido ético, de tutela da lisura e autenticidade da consulta eleitoral, voltado a coibir a interferência do poder econômico e da máquina estatal na formação do vontade coletiva.

A esse quadro de limitações de matiz extraordinária, alinhava-se, tradicionalmente, a regra da irreelegibilidade ${ }^{33}$ para os cargos do Executivo, como homenagem ao standard da alternância e modelado de forma a afastar os riscos do continuísmo e a deterioração do pólo do poder, por força da ação corrosiva de sua concentração, por um longo período, nas mãos de um grupo ou de um só homem.

A Emenda Constitucional n. 16, de 4 de junho de 1997, inovou no tocante ao tratamento desse instituto, suavizando a vedação para permitir que os titulares dos cargos de presidente da República, governador de Estado e prefeitos venham a postular por mais uma vez, em linha subseqüente, o mesmo posto $0^{34}$

A regra da possibilidade de recondução do Chefe máximo do Executivo, para mais um mandato consecutivo, encontra guarida na evolução do sistema presidencialista norte americano, quando, no ensejo de se recusar "replay" à pretensão do presidente Roosevelt de concorrer a um terceiro e quarto mandatos, foi consagrada, em esfera constitucional, com o advento e a retificação da Emenda n. XXII, a possibilidade de se pleitear uma e uma só vez a reeleição.

No panorama sul-americano, contudo, a prática afigura-se rara e de recente introdução. É o que denota a mais breve incursão no quadro dos sistemas eleitorais ali em vigor, onde se destacam, tão só, os exemplos da Argentina e do Peru, que passaram a agasalhar referida postura na década 90 , viabilizando a manutenção no poder dos respectivos presidentes.

De qualquer forma, o impacto da reeleição deflagrou novas limitações

31. Nesse sentido, a lição de André e Francine Demichcl (Droit Électoral, 1973, LD. Paris), e de Jean-Claude Maclet (Droit Électoral, 1989, PUF, Paris),

32. Lei Complementar Federal n. 64, de 18 de maio de 1990.

33. A regra da irreelegibilidade estréia entre nós com o texto da Constituição republicana de 189 | (art. 43), afigurando-se ausente tão-só na Carta de 1937.

34. Art. $14, \$ 5^{\circ}$ da Constituição Federal.(Reeleição). 
às campanhas $\mathrm{e}$, destarte, à liberdade de divulgar posturas e plataformas políticas, disputando a simpatia, a confiança e o voto dos eleitores.

Assim é que, a Lei n. 9.504, de 30 de setembro de 1997, texto editado, aliás, com proposta de permanência - para regulamentar várias e várias elcições, porquanto é categórico ao dispor na sua ementa: "estabelece normas para eleições" 35 - dedica todo um capítulo às "condutas vedadas aos agentes públicos em campanhas eleitorais" ( arts. 73 a 78), visando impedir o uso da máquina estatal, principalmente, por parte dos candidatos à reeleição. E as restrições introduzidas foram objeto de retorço por parte da Justiça Eleitoral, ao baixar as respectivas Instruções, culminando por impedir, de certa forma, até uma adequada segurança das autoridades, quando em campanha política.

Aliás, é de se registrar o dilerenciado tratamento oferecido pelo legislador no tocante à reeleição para os cargos do Legislativo. Nesse terreno, restou consagrada apenas a vedação quanto à utilização da gráfica para a produção de material publicitário. ${ }^{36}$ Nada mais, sob a argumentação de que o parlamentar deve se comunicar com o seu eleitorado. Mas aí resta a questão: o Chefe do Executivo, que hoje é eleito e cuja legitimidade encontra por superfícic exatamente o seu respaldo eleitoral, não seria merecedor de tratamento idêntico, mormente ante o "standard" igualitário que preordena os direitos consagrados no Estatuto Fundamentals?

De outra parte, convém reconhecer que, uma vez admitida a hipótese da reeleição, não há como ignorar o núcleo central em torno do qual gira o Instituto, ou scja a possibilidade que se abre ao eleitor de realizar uma opção por um programa de governo já em pleno desenvolvimento.

Pois bem, o instituto da reeleição, cm termos da viabilidade de recondução para o postos de Chefe do Poder Executivos, estreou no Brasil com a campanha de 1998, quando o presidente Fernando Henrique Cardoso pleiteou, conquistando nas urnas, mais um mandato presidencial. A emergência de situações mais complexas, contudo,

35. Entre nós, já era da tradição eleitoral a edição de un texto legal específico para cada pleito. É, sem dúvida, louvável a ação do legislador, produzindo um documento com o ar de generalidade e permanência, buscando, assim, evitar o casuísmo típico da esfera eleitoral. Aguarda-se, porém, com curiosidade, verificar em que medida a Lei n. 9 504/97 resistirá ao período de dois anos que a separa da próxima consulta - eleiçōes municipais do ano 2000.

36. Nesse sentido e de acentuada flexibilidade o tratamento assegurado, consagrado, inclusive em resposta do E. TSE a consulta promovida pelo presidente da Câmara dos Deputados, litteris: “Deputados. Trabalhos Gráficos. Possibilidade de que sejam fornecidos pela Câmara, no ano eleitoral, desde que relativos à atividade parlamentar e com obediência às normas extabelecidas em ato da Mesa, vedada sempre qualquer mensagem que tenha conotaşäo de propaganda eleitoral" (Consulta n. 444, Classe 5a. Distrito Federal, DJ 26.06.1998) 
verificou-se em esfera estadual, com a impugnação de candidaturas a Governador de Vice-Governadores que assumiram o governo por sucessão ao anterior titular.

O caso mais polêmico, de fato, girou em torno da figura do governador do Estado de São Paulo, Geraldo Alckmin, por duas vezes eleito vice de Mário Covas que veio a falecer em 2001, antes do término do mandato, quadro que elevou o vice à condição de governador, pretendente natural à conquista deste mesmo posto, por via eleitoral, nas eleições de 2002. O mecanismo jurídico a viabilizar esta candidatura: a reeleição.

Instado a se manifestar, por via da Consulta n. 689, o E. Tribunal Superior Eleitoral entendeu a pretensão plenamente afeiçoada ao preceito constitucional, porquanto o postulante tinha concorrido em dois pleitos consecutivos ao mandato de vice-governador. Encontrando-se empossado no cargo de governador, pela primeira vez, estaria pleiteando a recondução ao posto político de maior expoência do Estado e, para tanto, amparado pelo instituto constitucional da reeleição ${ }^{37}$. A postura favorável do E. T.S.E não chegou, todavia, a apaziguar a polêmica, sendo ressuscitada junto ao E. T.R.E. de São Paulo, por intermédio do respectivo processo de registro da candidatura, que sofreu impugnação. Memorável, pois, a decisão emanada do Tribunal paulista, ao proclamar - posição confirmada pela Suprema Corte - a conformidade constitucional da candidatura à reeleição postulada pelo governador Alckmin, contrariando o voto do relator; consagrouse, em síntese, a tese da possibilidade de um vice (vice-presidente, vice-governador, vice-prefeito) concorrer mais uma vez ao mandato de vice e, em seguida, sucedendo ao Chefe do Executivo, pleitear, por mais uma vez, este último cargo.

De qualquer forma, significativo o número dos que passaram a se utilizar da brecha da reeleição, submetendo à consulta popular o programa de governo e as políticas desenvolvidas no curso da respectiva gestão. No último pleito de 2002 , neste escaninho, foram detectados 8 candidaturas ao Governo do Estado a pleitear a reeleição, dos quais (4) quatro sagraram-se vitoriosos nas urnas ${ }^{38}$

\section{O Sistema Eleitoral}

A investigação das diversas e diversificadas facetas do processo eleitoral/

37. Resolução do TSE n. 20.889 (DJU 14.12.01). A Resolução de n. 21.026 reitera a solução oferecida anteriormente, confirmando a viabilidade da reeleição do Governador que, obtendo o cargo por sucessão, visa postular por mais uma vez sua candidatura ao posto.

38. Conquistaram mais um mandato, sucessivo, os Governadores: Geraldo Alckmin (São Paulo), Joaquim Roriz (Brasilia/DF), Flamarion Portela (Roraima), Zeca do PT (Mato Grosso do Sul). 
$2002^{39}$ conduz naturalmente à incursão no complexo panorama do sistema eleitoral entre nós adotado. Assim, necessário indigitar e visualizar os mecanismos e métodos empregados na seleção dos governantes e dos parlamentares para uma adequada radiografia dos resultados obtidos nas urnas. Pois bem, a escolha do Presidente e, em geral os pleitos para os cargos executivos, sob a égide da Constituição de 5 de outubro de 1988, atendem à técnica majoritária, em dois turnos, comum em espectro americano $^{40} \mathrm{E}$, no tocante à seleção dos representantes/parlamentares, o método é o proporcional, a seu turno dominante.

Clássica a assertiva de que o modelo majoritário, de duis turnos, acomodase melhor às sociedades pluralistas, em cujo âmbito é assegurada a criação e o funcionamento de múltiplos partidos. Num primeiro momento, permite-se ao eleitor clara manifestação quanto a sua preferência política; no segundo, porém, é autorizado o reagrupamento das forças políticas, restringindo-se as possibilidades de opção do corpo eleitoral. O segundo turno, a rigor, se consubstancia numa manifestação negativa, de eliminação.

A sua prática, no entanto, se afigura mais onerosa, importando num

39. As eleições de 2002 envolveram números gigantescos e uma acirrada disputa por cadeiras parlamentares: São Paulo (Câmara Federal 10,87 candidatos por vaga; Assembléia Legislativa 16,20 candidatos por vaga), Rio de Janeiro (Câmara Federal 13,23 candidatos por vaga; Assembléia Legislativa 19,57 candidatos por vaga), Minas Gerais (Câmara Federal 10,37 candidatos por vaga; Assembléia Legislativa 11,97 candidatos por vaga), Espírito Santo (Câmara Federal 11,8 candidatos por vaga; Assembléia Legislativa 13.2 candidatos por vaga), Sergipe (Câmara Federal 10,37 candidatos por vaga; Assembléia Legislativa 9,87 candidatos por vaga), Paraná (Câmara Federal 7,36 candidatos por vaga; Assembléia Legislativa 9,03 candidatos por vaga), Rio Grande do Sul (Câmara Federal 6,8 candidatos por vaga; Assembléia Legislativa 8,8 candidatos por vaga), Bahia (Câmara Federal 4,25 candidatos por vaga; Assembléia Legislativa 9,0 candidatos por vaga), Pernambuco (Câmara Federal 9.04 candidatos por vaga; Assembléia Legislativa 12.85candidatos por vaga), Paraíba (Câmara Federal 8,41 candidatos por vaga; Assembléia Legislativa 6,08 candidatos por vaga), Rio Grande do Norte (Câmara Federal II,I2 candidatos por vaga; Assembléia Legislativa 9,7 candidatos por vaga), Alagoas (Câmara Federal 11,33 candidatos por vaga; Assembléia Legislativa 9,85 candidatos por vaga), Ceará (Câmara Federal 7,04 candidatos por vaga; Assembléia Legislativa II,2 I candidatos por vaga), Piauí (Câmara Federal 8,6 candidatos por vaga; Assembléia Legislativa 6,8 candidatos por vaga), Maranhão (Câmara Federal 8,55 candidatos por vaga; Assembléia Legislativa 11,02 candidatos por vaga), Mato Grosso do Sul (Câmara Federal 13,12 candidatos por vaga; Assembléia Legislativa 9,83 candidatos por vaga), Mato Grosso (Câmara Federal 8,37 candidatos por vaga; Assembléia Legislativa 10,07 candidatos por vaga), Tocantins (Câmara Federal 8,0 candidatos por vaga; Assembléia Legislativa 11,29 candidatos por vaga), Distrito Federal (Câmara Federal 14,12 candidatos por vaga; Assembléia Legislativa 27,0 candidatos por vaga), Goiás (Câmara Federal 9,07 candidatos por vaga; Assembléia Legislativa 14,0 candidatos por vaga), Pará (Câmara Federal 7,88 candidatos por vaga; Assembléia Legislativa 12,21 candidatos por vaga), Amapá (Câmara Federal 8,37 candidatos por vaga; Assembléia Legislativa II,33 candidatos por vaga), Roraima (Câmara Federal 9,37 candidatos por vaga; Assembléia Legislativa 19,58 candidatos por vaga), Amazonas (Câmara Federal 9,5 candidatos por vaga; Assembléia Legislativa 17.75 candidatos por vaga), Acre (Câmara Federal 9,12 candidatos por vaga; Assembléia Legislativa 15,04 candidatos por vaga), Rondônia (Câmara Federal 14,62 candidatos por vaga; Assembléia Legislativa 15,87 candidalos por vaga). - Fonte: "O Estado de São Paulo, ed. de 26.08.2002, p. A 8.

40. Argentina, Bolívia, Chile, Costa Rica, Guatemala, Paraguai, dentre outros. 
processo eleitoral de significativos dispêndios. Daí as diversas propostas quanto a sua exclusão ${ }^{4 l}$ buscando-se alinhar o nosso padrão ao modelo majoritário por um turno, cuja prática pode ser detectada no México, Honduras, Panamá, etc.

Conquanto de difícil e cara aplicação, parece-nos que o formato majoritário por dois turnos, ainda, sc apresenta como de maior conformização a um quadro representativo que prestigic as minorias e melhor espelhe as perspectivas c expectativas da sociedade. Basta verilicar nesse sentido o panorama das eleições/ 2002. A nível presidencial, a bipolarização das lorças políticas, própria do "tour de ballotage" - como é conhecida a segunda clcição - rcorganizou partidos e facções, descortinando um quadro hetcrodoxo $\mathrm{cm}$ matéria de apoiamentos, onde se identifica:

\begin{tabular}{|c|c|c|c|}
\hline \multicolumn{2}{|l|}{ Candidato: Lula } & \multicolumn{2}{|l|}{ Candidato: José Serra } \\
\hline Personalidades/Grupos* & Partidos & Personalidades/Grupos* & Partidos \\
\hline $\begin{array}{l}\text { Ciro Gomes (PPS) } \\
\text { Candidato derrotado }\end{array}$ & PT & $\begin{array}{c}\text { Fernando Henrique Cardoso } \\
\text { Presidente }\end{array}$ & PSBD \\
\hline $\begin{array}{l}\text { Leonel Brizola } \\
\text { Presidente (PDT) }\end{array}$ & \begin{tabular}{|l} 
PMDB \\
(Parcial)
\end{tabular} & $\begin{array}{l}\text { Marco Maciel (PFL) } \\
\text { Vice- Presidente }\end{array}$ & $\overline{\mathrm{PFL}}$ \\
\hline $\begin{array}{l}\text { Roberto Freire } \\
\text { Presidente (PPS) }\end{array}$ & PSB & $\begin{array}{c}\text { Michel Temer } \\
\text { Presidente do PMDB }\end{array}$ & $\begin{array}{l}\text { PMDB } \\
\text { (Parcial) }\end{array}$ \\
\hline $\begin{array}{l}\text { Miguel Arracs } \\
\text { Presidente (PSB) }\end{array}$ & PDT & $\begin{array}{c}\text { Tasso Jcreissati } \\
\text { Scnador elcito pelo Ceará (PSDB) }\end{array}$ & $\begin{array}{c}\text { PPB } \\
\text { (Parcial) }\end{array}$ \\
\hline $\begin{array}{c}\text { Itamar Franco } \\
\text { Ex-presidente da República } \\
\text { governador de MG-sem partido }\end{array}$ & PPS & $\begin{array}{c}\text { Renan Calheiros } \\
\text { Senador clcito de Alagoas (PMDB) }\end{array}$ & PV \\
\hline $\begin{array}{c}\text { José Sarney } \\
\text { Ex-presidente } \\
\text { Senador pelo Amapá (PMDB) }\end{array}$ & PC do B & $\begin{array}{c}\text { Jarbas Vasconcelos } \\
\text { Governador reeleito de Pernambuco } \\
\text { (PMDB) }\end{array}$ & \\
\hline $\begin{array}{c}\text { Roseana Sarncy } \\
\text { Scnadora cleita do Maranhão (PFL) }\end{array}$ & $\mathrm{PL}$ & $\begin{array}{c}\text { Aćcio Neves } \\
\text { Governaldor cleito de MG (PSDB) }\end{array}$ & \\
\hline $\begin{array}{c}\text { Antônio Carlos Magalhães Senador } \\
\text { cleito da Bahia (PFL) }\end{array}$ & PTB & $\begin{array}{c}\text { Jaime Lerner } \\
\text { Governador do Paraná (PFL) }\end{array}$ & \\
\hline $\begin{array}{c}\text { Ronaldo Lessa Governador reeleito de } \\
\text { Alagoas (PSB) }\end{array}$ & & $\begin{array}{c}\text { Francisco Dornelles } \\
\text { Deputado rceleito (PPB) }\end{array}$ & \\
\hline $\begin{array}{c}\text { Orestes Quércia Ex-governador de } \\
\text { São Paulo (PMDB) }\end{array}$ & & $\begin{array}{c}\text { Inocêncio Oliveira } \\
\text { Líder na Câmara (PFL/PE) }\end{array}$ & \\
\hline \multirow[t]{2}{*}{$\begin{array}{c}\text { Luiz Henrique Silveira } \\
\text { Candidato ao governo de Santa } \\
\text { Catarina (PMDB) }\end{array}$} & & $\begin{array}{c}\text { Geddel Vieira Lima } \\
\text { Líder na Câmara (PMDB/BA) }\end{array}$ & \\
\hline & & Roberto Brant (PFL-MG) - deputado & \\
\hline
\end{tabular}

* lontc: O Estado de S. Paulo, ed. De 9.10.02, p. H1.

41. PEC ns. 096/95, 022/95, 093/95, 06I/95, 250/95, 282/95, 197/95. 
No primeiro turno o candidato que, afinal, se sagrou vencedor, Luiz Inácio Lula da Silva, obteve $46,4 \%$ dos votos válidos, uma diferença bastante significativa do segundo posicionado, José Serra, com 23,2\%. Afinal, a vitória foi conquistada em 27 de outubro de 2002 , com $61,3 \%$ dos votos válidos, contra os $38,7 \%$ obtidos pelo seu opositor.

Em terreno estadual, dentre os 27 Estados que compõem a federação brasileira, em apenas 10 foi aplicada a regra do "ballotage" impondo-se um segundo Iurno. Neste particular espectro, contudo, interessante verificar como, em algumas hipóteses, candidatos que, ao início da campanha, contavam com uma significativa força eleitoral, sofreram sensível fragilização, a exemplo de Joaquim Roriz do Distrito Federal que, surpreendentemente, teve que se valer do segundo turno para sua reeleição. Em São Paulo, de outra parte, este segundo turno teve condão de fortalecer a liderança do governador reeleito, Geraldo Alckimin. No primeiro turno foi contemplado com $38,3 \%$ da votação válida e no segundo obteve $58,6 \%$, conquistando razoável legitimidade.

De outra parte, a regra do segundo turno beneficia o eleitor com um período maior para reflexão. Disso decorreu, também, o resultado final do pleito de 2002, panorama que oferece um amplíssimo respaldo político-eleitoral, pessoal, em rclação ao presidente eleito - Lula, não the autorizando, porém, este mesmo suporte político em relação ao partido que representa e sob cuja legenda foi eleito. Constata-se, neste cenário, que, embora eleito com $61,3 \%$ dos votos válidos, os candidatos a governador, pelo PT, conquistaram apenas 33,3\% dos votos válidos, elegendo três governadores (Acre, Mato Grosso do Sul e Piauí). No tocante à bancada parlamentar, o PT elegeu $17 \%$ das cadeiras do Senado e $18 \%$ dos assentos da Câmara dos Deputados. ${ }^{42}$

Em verdade as críticas direcionadas à adoção do sistema majoritário por dois turnos para a escolha do Presidente da República, dos Governadores de Estado e dos Prefeitos foram mais severas no âmbito da consulta eleitoral - 2002 em razão do clevadíssimo custo derivado do prolongamento da campanha, reflexo inafastável do sisıcma. Além disso, apenas em um terço (1/3) dos Estados se fez necessária a consulta complementar, um indicador do amadurecimento do eleitor. E mais ainda, na grande maioria dos Estados, no âmbito dos quais foi realizado o "tour de ballotage", o vencedor, de fato, já detinha a preferência cleitoral já no primeiro turno. Nesta hipótese a situação de São Paulo, Ceará, Sergipe, Rio Grande do Sul, Distrito Federal e Mato Grosso do Sul. Todos estes fatores são apontados como indicadores da dispensabilidade do segundo turno e retorno ao majoritário puro - the first past the post.

O ponto nevrálgico da questão, no entanto, não repousa na discussão

42. Fonte: Revista "Veja", ed. De 6.11.2002, p. 52 e segs. 
acerca do amadurecimento do eleitor ou a sua preparação política. Também não se deve discutir o ônus financeiro imposto por este segundo turno. Os instrumentos para a prática da democracia afiguram-se dispendiosos. É mister anotar que a própria democracia configura um regime exigente. E nesse contexto não há como ignorar que o denominado "tour de ballotage"4,3 importa, na realidade, na exigência de maioria absoluta para indigitar o vencedor da disputa eleitoral. Aliás, diante de quadros multipartidários, esta técnica se oferece como a mais adequada, como se vislumbra da clássica observação de Duverger: “... um único turno afigura-se insuficiente - sendoindispensável o segundo turno" 44 Forçoso convir que a legitimação do poder e, até mais que isto, a consistência do suporte político, elemento intrínseco à expectativa de governabilidade, resultam de forma muito mais robusta a partir de um sistema majoritário por dois turnos do que respaldado, tão-só, no majoritário simples, que conduz ao poder, não raras vezes, candidatos contemplados com o voto de uma minoria.

De maior polêmica, o segmento em que reina a técnica da proporcionalidade - as eleições parlamentares. Isto porque, embora o modelo seja o que mais se afeiçoa à expectativa de representação do maior número de setores da comunidade social, ${ }^{45}$ as peculiaridades do padrão adotado em paisagem doméstica, brasileira, enseja desvios e relevantes falhas.

Com efeito, o método desenhado pelo legislador aponta para o subsistema do Quociente Eleitoral, acoplado ao Quociente Partidário, sendo a partilha das sobras operacionalizada pela técnica da maior média ${ }^{46}$ Importa, na verdade, em três diferentes

43. Historicamente identifica-se a exigência da maioria absoluta no meio eclesiástico, adotando-se a prática a partir do Conselho de Latran. Utilizada para a seleção dos senadores municipais das velhas cidades do Império Romano, foi, posteriorınente, detectada na França, quanto ao processo de designação dos deputados dos Estados Gerais. Repudiada na Segunda República francesa, a regra foi restabelecida no Segundo Império, sendo acolhida, hoje, na grande parte dos países europeus que se inspiraram nas técnicas francesas. Ver o nosso Sistemas Eleitorais X Representação Política, op. cit., p. 138 e ss.

44. DUVERGER, Maurice, Institutions Politiques et Droil Constitutionnel, Paris, PUF, 1971, p 173.

45. O modelo conhecido como "sistema proporcional" gira em torno da idéia de que o número de votos atribuídos a um partido deve ser proporcional ao número de cadeiras por esse obtido, visando numa perspectiva de assegurar equidade e justiça no campo da disputa eleitoral - conferir a cada uma das agremiações político-partidárias a sua real cota de participação no processo de distribuição das vagas do Legislativo. Costuma-se atribuir a Thomas Hare, advogado londrino, o mérito da introdução da idéia da proporcionalidade aplicável à eslèra eleitoral. Na verdade, o sistema foi aplicado pela primeira vez na Bélgica, eın 1899, com a adoção da proposta do professor de Direito e matemático Victor d'Hondt a subsidiar projeto de lei apresentado pelo ministro da Justiça, Van den Hecuven. V. nosso Sistemas Eleitorais $X$ Representasaion Politica, op. cit. sup. P. 149 e segs.

46. Código Eleitoral (Lei n. 4.737/65), arts. 106, I07, 108 e 109. Ver o mecanismo do sistema do Quociente Eleitoral acoplado à técnica da maior ınédia, para as sobras, no nosso Sistemas Eleitorais $X$ Representaçāo Política, op. cit. 
opcrações, todas voltadas a privilegiar a figura do partido político e, porque não dizer, daqueles de maior densidade eleitoral, porquanto na distribuição das sobras são os partidos com maior votação que acabam sendo contemplados com o maior número de cadciras parlamentares restantes (as sobras) ${ }^{47}$

O sistema, como já anotado, gira cm torno da entidade - partido político. Retira da disputa as agremiações que não alcancem o QE (quociente eleitoral), independentemente da boa votação que alguns de seus candidatos possam ter obtido. De outra parte, acaba contemplando com cadeiras parlamentares os partidos ou coligações que, no conjunto de candidaturas apresentadas, maior número de votos alcançaram. E esta operação pode, por vezes, resultar na produção de verdadeiras ficções cleitorais, a exemplo do caso PRONA que escandalizou os eleitores com a deturpação verificada no grau de representatividade dos eleitos.

Pois bem, no episódio vivenciado pclo PRONA (eleições/2002), o partido conquistou scis cadeiras parlamentares (Câmara Federal) apoiado, apenas e tão só, na votação obtida pelo seu líder, Enéas (1.572.292). Os demais eleitos não detêm o menor nível de representatividade. Obtiveram um número de sufrágios absolutamente irrisório (Amauri R. Gasques /18.409 votos, Irapuan Teixeira $/ 672$ votos, Elimar/ 483 votos, Ildeu Araújo/ 382 votos, Vanderlei Assis/ 275 votos) e muito inferior à média de votos necessária para se eleger, i.é de aproximadamente $100.00^{48}$ Aludida ausência de representatividade, aliás, deriva da própria ausência de vínculo com São Paulo, circunscrição pela qual se elegeram. Não residem nesta circunscrição e, suscitada a qucstão atinente à falsidade das declarações quanto ao domicílio, quatro destes candidatos $^{49}$ tiveram as transferências dos respectivos títulos de eleitor canceladas, sendo interpostos, a seguir, pela Procuradoria Elcitoral, recursos contra a diplomação. Aguardase o julgamento destes recursos, havendo esperança de que, eventualmente, podcrão

47. Nas eleições de 2002, foraın contemplados na distribuição das sobras, pela técnica da maior média: PT - 14 cadeiras; PSDB - 12 cadeiras; PPB - 10 cadeiras; PFL - 11 cadeiras; PTB - 4 cadeiras; PL - 4 cadeiras; PPS - 3 cadeiras; PSB - 3 cadeiras; PDT -2 cadeiras; PC do B - I cadeira; PRONA - 1 cadeira; PSD - I cadeira; PV - I cadeira. Fonte: site do T.S.E.

48. Situação similar verificou-se junto à Assembléia Legislativa do Estado de São Paulo, onde o PRONA conquistou 4 cadeiras: Dra. Havanir - 681.649, Said Mourad - 13.130, Paulo Sérgio - 11.6I4 e Adilson Barroso - 9.928. Ainda neste ambiente, interessante verificar como o estoque de votos, particular Ja Dra Havanir, acabou elegendo deputados sem qualquer expressão eleitoral, com uma votação muito inferior à média necessária para a obtenção do mandato parlamentar, emn torno de 60.000 votos. Aliás, a votaçāo mais baixa a lograr uma cadeira na Assembléia Legislativa foi o Pastor Bittencourt, do PGT, coın 35.745 votos, quase três vezes superior ao número de votos obtido pelo segundo colocado do PRONA.

49. Irapuan Teixeira, Elimar Máximo Damasceno, Ildeu Araújo e Vanderlei Assis. 
tais candidatos, meras ficções, perder a vaga, sendo que nesta hipótese, novo desafio scrá trazido a lume: o PRONA não tem suplentes, em razão da telegráfica lista de candidaturas que apresentou. Assim, em se verificando a invalidação dos diplomas, serão abertas 4 vagas na Bancada que São Paulo detém na Câmara Federal, sendo que a ausência de suplentes, importa na exigência de novas eleições para o provimento destas vagas, ex vi do preceito do art. 113 do diploma eleitoral em vigor (Lei n. 4.737/65).

O fenômeno PRONA, que logrou demonstrar os efeitos perversos para a qualidade da representação do padrão proporcional aplicado com vinculação total ao quadro partidário, impõe, a este passo, um especial debruçar sobre os mecanismos da representação política preconizados pela Constituição. Reclama até maior atenção no locante à necessidade de um novo esforço de reengenharia eleitoral e partidária, conduzindo à retomada dos debates acerca da Reforma Política. E não há que ignorar que no bloco das mutações propostas permanece inerte a proposta do voto distrital, que, certamente, iria minimizar as possibilidades de ocorrência dessa espécie de desvio na representação política.

É que o voto distrital implica no provimento de $50 \%$ (poderia ser qualquer outra porcentagem- $25 \%, 60 \%, 40 \%$ ) das cadeiras parlamentares pelo voto majoritário puro, sufrágio uninominal, votando-se no candidato e sagrando-se vitoriosos os candidatos que, de per si, conquistaram o maior número de sufrágios. O restante das vagas seriam distribuídas pela técnica proporcional, sede em que se leva em consideração, em primeiro lugar, o número de votos obtidos pela legenda; reflexo disso, cvidentemente, quando se está na presença de partidos de pequena envergadura, que sobrevivem à custa da imagem única e exclusiva do seu líder, a redução da bancada "ficção" obtida pelo PRONA, no âmbito da qual, tão-só, Enéas teve uma votação expressiva e, portanto, respaldo eleitoral, encontrando-se os demais afastados de qualquer grau de representatividade.

Além da conhecida e debatida técnica do "voto distrital", que encontra importantes simpatizantes em cenário político e, a cada nova legislatura, ingressa na pauta parlamentar por breves períodos para, a seguir, retornar à penumbra das gavetas do nosso Congresso, oportuno se nos afigura o exame mais detido do método misto, conhecido como voto único transferível, advogado, já ao final do século XIX, por Thomas Hare ${ }^{50}$ É que referido sistema autoriza uma valoração efetiva da vontade polílica expressa nas urnas pelo eleitor, abrindo, a seu favor, a possibilidade de indicar Malta.

50. Ver nota n. 45, segunda parte. O sistema do voto único transferível é aplicado na Irianda e em 
preferências: a primeira, a segunda, a terceira... Demais disso, viabiliza uma partilha das cadeiras, entre os candidatos, mais democrática e com maior enfoque para a exigência da representatividade. Neste contexto, o eleitor deve sufragar um só candidato; o seu voto, no entanto, é transferido para outro candidato de sua preferência, caso aquele que constou como primcira prelerência tenha sido ẹleito ou, ainda, tenha obtido um número muito pequeno de votos, inferior ao exigido, e que não detém condições de se eleger.

A técnica se oferece, talvez, de maior complexidade. Prevê uma primeira opcração, por intermédio da qual define-se o quociente eleitoral (QE), e uma atividade sucessiva compreendendo operações complementares de mensuração e atribuição das preferências. No entanto, sua aplicação evitaria a produção de bancadas de ficção, sem qualquer consistência eleitoral e de questionável representatividade.

Elcições 2002 e o fator financeiro ${ }^{5 \prime}$

Em verdade, nos cenários cleitorais, a luta que é travada constitui pura disputa de poder ou a busca de prestígio. Daí porque o dinheiro comparece como algo instrumental, o meio que viabiliza alcançar o poder, o prestígio ou outros objetivos perseguidos. Por isso, relevante é identificar a sua origem, como, ainda, o seu destino, ou seja como é gasto, pois essa é a trilha que irá desvendar a linha utilizada para a conquista de influência a ser convertida em outras vantagens e recursos próprios da esfera do poder político. Nesse sentido a advertência de Herbert E. Alexander: “...money also is a tracer element in the study of political power. Light thrown upon transactions involving money illuminates political processes and behavior and improves understanding of the flow of inluence and power." 52

Forçoso convir, pois, a impositiva exigencia do exame do sistema de controle a envolver o pleito de 2002, inquirindo-se acerca de sua acomodação à necessidade de assegurar a integridade do processo eleitoral, porquanto o que deve se perseguir é exalamente a luminosidade que deve estar presente, sempre, sobre as atividades de arrecadação e gastos de partidos e candidatos.

Com efeito, esta luminosidade a abarcar a atividade financeira envolvendo as eleições oferece-se como elemento primordial a partir dos dados extraídos da realidade das campanhas políticas, onde poderiam ser destacados os seguintes números:

51. Ver o nosso trabalho: O Financiamento das Campanhas Eleitorais e Seu Controle, in Revista Direito/Mackenzie, São Paulo, 2002, p. 87.

52. ALEXANDER, Herbert E., "Financing Politics-Money Elections and Political Reform". Washington,DC, Congressional Quartely Press, Foreword, Fourth Edition, 1992, p. 3 
O custo estimado da campanha eleitoral de 2002, variando de acordo com o tamanho do eleitorado. (em milhões de reais)

\begin{tabular}{|c|c|c|c|}
\hline & Grande (São Paulo) & Médio (Pará) & Pequeno (Roraima) \\
\hline Estrutura & 14,7 & 3,5 & 2,2 \\
\hline Brindes & 5,1 & 1,5 & 0,3 \\
\hline TV/Pesquisas & 15,7 & 7,3 & 2,4 \\
\hline Comícios/carreatas & 5,5 & 1,5 & 0,8 \\
\hline Propaganda & 3,9 & 1,09 & 0,3 \\
\hline
\end{tabular}

Fonte: O Estado de São Paulo, ed. de 24 de março de 2002, p. A6

E mais até, os registros apontam vultosas quantias em relação ao valor do voto. Neste sentido, os estudos promovidos pela Justiça Eleitoral demonstraram que:

I) A campanha vencedora (Lula) gastou $R \$ 0,64$, por voto, $R \$ 298$ mil por dia de campanha e $\mathrm{R} \$ 33,7$ milhões no total;

2) Serra (o candidato derrotado no $2^{\prime \prime}$ turno) desenbolsou: R\$1,03 por voto, R $\$ 304$ mil por dia de campanha e R \$34,4 milhões no total;

3) Dos candidatos que se apresentaram às eleições presidenciais, o voto conferido a Ciro Gomes (derrotado já no l" turno) foi o mais caro: $\mathrm{R} \$ 1,59$, tendo desembolsado $\mathrm{R} \$ 176$ mil por dia e R\$16,2 milhões no tolal.

Pois bem, neste específico espectro, dois, a nosso ver, constituem os pontos nevrálgicos do tema atinente ao controle da faceta financeira do processo eleitoral. O primeiro consiste em definir o campo que deve ser submetido a controle. $O$ que se deve fiscalizar e em que momentos.

Já sob um outro enfoque é mister impedir que o controle incidente sobre as operações financeiras dos partidos - em períodos pré-eleitorais ou-não - venha a nulificar o direito de livre manifestação e exteriorização do pensamento, a liberdade de atuação política, de pregação, de batalhar pela conquista dos votos, enfïm de agir politicamente buscando expandir a respectiva densidade eleitoral, ampliar sua representatividade, perseguir o atingimento d́a meta máxima que é a de alcançar o poder ${ }^{53}$

Tradução nossa: “... o dimheiro constitui traşo elementar ao estudo do poder político. Comhecer as ransagöes que envolvem dinheiro coloca à luz os processoss políricos e o comportamento e implementa o) emtendimento acerca das ondas de flutuaţüo das influências e do poder."

53. A liberdade de manifestação - a liberdade da palavra - $\mathrm{em}$ períodos eleitorais, o que impede limitações excessivas sobre os gastos que os candidatos venham a realizar para poder alcançar os seus eleitores, foi um dos pontos consagrados por força da decisão BUKLEY X VALEO, (proferida em 30 de janeiro de 1976, pela Suprema Corte dos Estados Unidos. A discussão girava em torno das liınitações de 


\section{Objeto do Controle}

Pois bem, sob o prisma da área sujcita à vigilância, contrariamente ao que usualmente ocorre, ou seja, uma preocupação específica voltada aos gastos clcitorais, parece-nos irretorquível o fato de que a sua incidência tanto deve recair sobre a arrecadação e as fontes desses aportes, como, ainda, sobre as despesas, cscaninho que implica na verificação da legitimidade, do montante de recursos utilizados e a moralidade dos meios e técnicas a envolver sua aplicação. Isto porque a oblenção de recursos financeiros, além de árdua, oferece-se de extrema periculosidade, porquanto é nesta etapa que se descortina um promissor campo à ação corruptora de clcmentos ou organizações que, por intermédio do financiamento das campanhas, visam conquistar margens de influência nos canais decisórios do Estado. ${ }^{54}$

Assim é que, nó panorama definido pelos americanos sob rótulo de "raising the money" (fund raising- uma especialidade, hoje em dia, bastante valorizada), é que o analista detecta um ponto de alta vulnerabilidade a abrir a porta para a atuação desintegradora dos lobbies, o uso indireto e indevido da máquina estatal e, ainda, a interferência da fortuna pessoal que acaba por desequilibrar o ambiente da disputa.

Entre nós, o legislador, ao editar a Lei n. 9.504, de 30 de setembro de 1997, estabeleceu normas mais consentâneas com as práticas de arrecadação de fundos,

campanha introduzidas pela Emenda de 1974 c acabou impondo ao Congresso norte-americano a revisão do quadro normativo em 30 dias. Ver a respeito: HERBERT E. ALEXANDER, Financing Politics, Money, Elections \& Political Reform, 4a ed., Washington, DC, Congressional Quartely Press, Foreword, Fourth Edition, 1992, e nosso FINANÇAS PARTIDÁRIAS, op., cit. p. 68 e 69.) E, mais recentemente, na GrãBretanha, atrai a atenção dos analistas o caso Bowınan, que provocou decisão emanada da Corte Européia, similar ao precedente norte-americano, acima referido, no sentido de que os limites estabelecidos para fins de despesas eleitorais não podem representar restrição injustificável à liberdade de expressão. Cuidavase nesse caso de ação levada a efeito por Phyllis Bowman, diretora executiva da Sociedade para a Proteçāo dos Nascituros (SPUC - Society for the Protection of the Unborn Child). No período anterior às eleições inglesas de 1992, Phyllis distribuiu milhares de folhetos e volantes de propaganda de 3 candidatos, principalmente no colégio eleitoral de Halifax. Acusada de ter violado o art. 75 do Representation of the People Act, por gastos excedentes na proınoção de campanha eleitoral de candidato e sem a autorização deste - simplesınente na qualidade de terceiros simpatizantes - Bowman levou o caso à Corte Européia, onde obteve referida decisão favorável e que, de certa forına, interferiu nos estudos que estāo sendo realizados na Inglaterra em busca de uma remodelação da legislação eleitoral, incluindo a questão do financiamento. (Neste sentido as Comissões: Ncill Comittee e Lord Jenkins Comittee) - FISHER, Justin, II Finanziamento dei Partiti Politici in Gran Bretagna, in Finamziamento della Politica e Corruziome, A cura de LANCHESTER, Fulco, Milão, Dott. A . Giuffrè Editore, 2000.

54. Theodor Roosevelt, aliás, já em 1905 já reclamava pela necessidade de vedação de contribuições a partidos e a candidatos, recomendando que a lei viesse a proibir "todas as contribuiçōes oferecidas por associações a qualquer partido político ou para qualquer fím político" (in Finanças Partidárias, Mônica Herman S. Caggiano, op. cit. sup., p. 18/19). 
reconhecendo e regulamentando a captação de recursos no âmbito da esfera privada, de pessoas físicas e jurídicas, de molde a assegurar um determinado equilíbrio à campanha, e a transparência necessária a identilicar as fontes de financiamento que operam por de trás dos partidos e dos candidalos, enfím medidas que buscam garantir a lisura e a autenticidade das consultas. Aprimorou o mecanismo pertinente à inserção de tetos máximos de contribuição e accrca do controle das interferências advindas da utilização dos bens públicos.

O tema, aliás, $v e m$ tratado $\mathrm{cm}$ capítulo especílico, sob a rubrica "Da Arrecadação e da Aplicação de Recursos nas Campanhas Eleitorais" (Lei n. 9 504, de 30 de setembro de 1997, arts. 17 a 27), preceitos que, no entanto, não detém exclusividade na regulamentação, porquanto outras normas, inseridas no bojo de textos legislativos diferentes, a exemplo da Lci Orgânica dos Partidos Políticos (Lei n. 9.096, de 19 de setembro de 1995), a scu turno cuidam da matćria.

De forma geral, os aportes autorizados, nos termos do art. 20 do referido diploma (Lei n. 9 504, de 30 de setembro de 1997), devem advir do próprio partido, do comitê financeiro, do Fundo Partidário (sempre canalizados por intermédio dos partidos), de pessoas físicas ou jurídicas (excluídos aquelas sobre as quais incidem vedações - art. 24), e recursos próprios do candidato.

Interessante a perspectiva do legislador brasileiro que admite doações de pessoas físicas para campanhas eleitorais, somente, "a partir do registro dos comitês financeiros" - (art. 23 Lei 11. 9 504/ 1997), cnquanto que na França, por exemplo, sc reconhece o fato de que, durante todo o ano que precede as eleições, essa atividade deve ser permitida e regulada (artigo L. 52-4, do Código Eleitoral, por força de alteração introduzida em 1995) 5.5

Restam vedadas, no cntanto, contribuições oriundas de: entidades ou governos estrangeiros, órgãos da Administração Pública Direta ou Indircla, concessionários ou permissionárias de serviços públicos, entidades de utilidade pública, sindicatos, pessoas jurídicas que recebam auxílios financeiros estrangeiros ou beneficiados com contribuições compulsórias fixadas por lei e, ainda, cataloga o legislador, na rubrica de ingressos fïnanceiros indevidos, quaisquer colaborações à campanha, por meio de material, scrviços, locação de bens e uma série de condutas que implicam em recursos olerecidos de lorma camuflada (Lei n. 9 504/97, art. 26).

Singular a norma do art. 27 , da já assinalada lei clcitoral, que consagra,

55. MANOD, Alain, Le Financement des Campagnes Électorales, Paris, Berger Levrault, setembro de 2000 . 
entre nós, embora ainda de forma tímida, prática já consolidada em território norteamericano. Trata-se da debatida atuação dos Political Action Comittees, organizações de simpatizantes das campanhas político-clcitorais que são constituídos por ocasião dos momentos pré-eleitorais e que atuam no domínio do "fund raising" arrecadando contribuições de reduzido valor, sem necessidade de registro quanto à origem. Importa, scm dúvida, numa fórmula de estimular a participação política e o exercício da cidadania. Implica, no entanto, também, num mecanismo de arrecadação e de realização de despesas de campanha fora do alcance do controle efetivo que ć proposto nesse domínio ${ }^{56}$

De fato, introduz aquele preceito (art. 27 da Lei n. 9.504/97) nova modalidade de colaboração com campanhas político-eleitorais: a possibilidade de qualquer eleitor "realizar gastos, em apoio a candidato de sua preferência, até a quantia equivalente a um mil UFIR, não sujeitos a contabilização, desde que não reembolsados." Ora, a técnica é excelente c oferece a brecha para, por via de múltiplas c pequenas contribuições, passe o dinheiro de campanhas a circular por uma via marginal, sem qualquer transparência c a salvo de qualquer controle ${ }^{57}$

O impacto da Emenda Constitucional n. 16, de 4 de junho de 1997, que, em moldes já assinalados, inovou no tocante ao tratamento do instituto da irrecelegibilidade, suavizando a vedação para permitir que os titulares dos cargos de Presidente da República, Governador de Estado e Prefeitos venham a postular por mais uma vez, em linha subseqüente, o mesmo posto, deflagrou novas limitações às campanhas c, destarte, à liberdade de divulgar posturas c plataformas políticas, disputando a simpatia, a confiança e o voto dos cleitores.

Assim é que, a Lei n. 9. 504, de 30 de setembro de 1997, dedica todo um

56. cf. HERBERT E. ALEXANDER, Financing Politics, Momey, Elections \& Political Reform, 4a ed., Washington, DC, Congressional Quartely Press, Foreword, Fourth Edition, 1992.

57. Referida possibilidade de arrecadar pequenas quantias (de muitos) lembra a polêmica e discutida técnica dos PAC's que dominam o quadro eleitoral estaludinense. São os Political Action Comillees, que podem ser inaugurados e mantidos por amigos e simpatizantes dos candidatos. Toda a contabilidade corre por conta desses comitês que, a rigor, atuam em prol da candidatura que suportam. Podemn receber doaçóes até um determinado limite e, por vezes, até de fontes que não poderiam financiar partidos e candidatos diretamente, a exemplo de sindicatos; podemn doar importâncias (até uın deterıninado limite, dependendo da legislação do respectivo Estado) a partidos políticos e candidatos; enfim gozam de uma acentuada liberdade de manipulação de orçamento de campanha, muito mais aınpla que a admitida em relação a partidos e candidatos. É verdade que nos domínios norteamericanos, onde cada Estado conta com sua própria legislação eleitoral, inclusive em matéria de "fund raising" há registros de tratamentos diferenciados, buscando-se limitar a interveniência dos PAC's no linanciamento de candidaturas, em especial, introduzindo limites aos montantes com que tais organizaçōes podem doar à campanha. In HERBERT E. ALEXANDER, Financing Politics, Money: Elections \& Political Reform, 4a ed., Washington, I)C, Congressional Quartely Press, Foreword, Fourth Edition, 1992. 
capítulo às "condutas vedadas aos agentes píblicos em campanhas eleitorais" (arts. 73 a 78 - Condutas Vedadas aos Agentes Públicos em Campanhas Eleitorais), visando impedir o uso da máquina estatal, principalmente, por parte dos candidatos à recleição. E mais, as restrições introduzidas foram objeto de reforço por parte da Justiça Elcitoral, ao baixar as respectivas Instruções, culminando por impedir, de certa forma, até uma adequada segurança das autoridades, quando em campanha política. Dentre tais proibições pode-se destacar:

a) a impossibilidade de participação das campanhas políticas de asscssores ou funcionários subordinados ao pretendente à reeleição, impondo-lhes, para tanto, prévio afastamento do cargo, o que na prática impunha a realização de atos de campanha eleitoral com vistas à recondução de uma equipe governamental e para a continuidade do programa desenvolvido por essa mesma equipe, porém sem a equipe essa tarefa restou atribuída com exclusividade ao respectivo chefe;

b) a impossibilidade de uso de veículo oficial para comparecer a atos de campanha - avião ou automóvel. Paradoxalmentc, o corpo de segurança poderia se deslocar com veículos oliciais e, na hipólese de acronave, o usuário restaria obrigado a ressarcir o erário público pelo valor da viagem. A regra logo fez a primeira vílima, - Ministro da Saúde que se utilizou de acronave da Companhia Energética de São Paulo para se deslocar de São Paulo a Piracicaba, para reunião de "cunho políticopartidária" como alcunhado referido encontro, enscjando a instalação de processo judicial e condenação da autoridade;

c) neutralidade por parte da equipe de segurança que eventualmente acompanhar a autoridade a eventos de campanha, no sentido de the restar vedada a possibilidade de distribuição de matcrial ou ato que pudesse ser considerado como de propaganda do candidato;

d) aparclhos de telefone e fax do candidato a reeleição não podem scr utilizados para contatos de campanha;

c) residência oficial não podendo ser utilizada para jantares ou eventos que possam vir a ser qualificados como reuniões de campanha político-eleitoral.

Digna de nota, aliás, a última das hipóteses arroladas, a partir do elenco restritivo a incidir sobre os postulantes a mais um mandato. Isto porque não há como impedir alguém de receber, no local da sua moradia, quem quer que seja. Não dando abrigo a criminosos, a inviolạbilidade do domicílio é princípio constitucional, tcrritório que assegura, também, o dircito à privacidade.

Portanto ilusório que tal norma viria a impedir a realização de jantares 
e almoços com personalidades importantes na trajetória da reeleição. Nem há que se falar, ademais, que a técnica "Jantar com o Presidente" conligura uma das mais antigas e tradicionais no catálogo do "Fund Raising" vindo a se celebrizar, na análise procedida pelo prof. Herbert E. Alexander, como financiamento "on the cash and calorie plan" $5 \times /$ s". Absurda a regra, ainda, porque impraticável uma eficaz fiscalização, passando a sc afigurar muito difícil a comprovação de eventual incidência. Rellete um dispositivo fadado a servir de simples fachada e a uma triste permanência no papel.

Restou vedado mais: a publicidade institucional, salvo em caso de grave c urgente necessidade pública, assim entendida pela Justiça Eleitoral, e quaisquer pronunciamentos em cadeia de rádio e televisão fora do horário eleitoral gratuito, excetuando-se as hipóteses de urgência, a critério da Justiça Eleitoral (art. 73, VI, be c), postura legislativa que reintroduziu, entre nós, a censura, abolida pela Constituição de 5 de outubro de 1988.

Aliás, é de se registrar o diferenciado tratamento oferecido pelo legislador no tocante à reeleição para os cargos do Legislativo. Nesse terreno, restou consagrada apenas a vedação quanto à utilização da Grálica para a produção de matcrial publicitário. ${ }^{(1)}$ Nada mais, sob a argumentação de que o parlamentar deve se comunicar com o scu eleitorado. Mas aí resta a questão: o Chefe do Executivo, que hoje é clcito c cuja legitimidade encontra por superlícic exatamente o seu respaldo cleitoral, não seria merecedor de tratamento idêntico, mormente ante o "standard" igualitário que preordena os direitos consagrados no Estatuto Fundamental?

De outra parte, convém reconhecer que, uma vez admitida a hipótese da recleição, não há como ignorar o núcleo central em torno do qual gira o Instituto, ou scja a possibilidade que se abre ao eleitor de realizar uma opção por um programa de governo já em pleno desenvolvimento.

58. Money in Politics, PAP, 1972, Washington, D.C. e Financing Politics, Congressional Inc. April, 1978.

59. Interessante a esse respeito verificar os métodos "on the cash and calorie plan" utilizados na recleição do presidente Clinton, eleições de 1996. São apontadas nesse período as seguintes alternativas: uma contribuição de cerca de US\$2.5 mil confere o direito a evento com o vice-presidente Al Gore; o dobro dessa contribuição implica na possibilidade de uma reunião de 10 pessoas, na Casa Branca, para ver o presidente e US $\$ 100$ mil viabiliza um jantar com o presidente no Hay Adams Hotel, na frente da Casa Branca. (apud Times, novembro 11 - 1996, p. 15)

60. Nesse sentido e de acentuada flexibilidade o tratamento assegurado, consagrado, inclusive em resposta do E. TSE a consulta promovida pelo Presidente da Câmara dos Deputados, litteris: "Deputados. Trabalhos Grálicos. Possibilidade de que sejam fornecidos pela Câmara, no ano eleitoral, desde que relativos à atividade parlamentar e com obediência às normas estabelecidas eın ato da Mesa, vedada sempre qualquer mensagem que tenha conotação de propaganda eleitoral" (Consulta n. 444, Classe 5a. Distrito Federal, DJ 26.06.1998) 
Desse mesmo sentir, a linha jurisprudencial construída a partir dessas novas hipóteses restritivas do texto legal. Assim, na Representação cleitoral n. 68 Distrito Federal, o Relator, ministro Garcia Vicira, do E. Tribunal Superior Elcitoral, em scu voto vencedor, pronunciou-sc: "A ação governamental do Ministro de Estado da Previdência e Assistência Social, além de legítima, no âmbito de suas responsabilidades constitucionais e funcionais, não configurando propaganda eleitoral, mas, no máximo, publicidade institucional autorizada por lei ......, em nada permite conchir sobre "conduta tendente a afetar a igualdade de oportunidade entre candidatos" da parte do Presidente da República. A lei não poderia (para ser constitucional) e não pretendeu paralisar a ação governamental, de forma compatível com a correta exegese da Emenda Constitucional n. 16/97, que, segundo orientação jurisprudencial deste Egrégio TSE e do Colendo STF, ao introduzir a possibilidade de reeleição para o Executivo, observa o princípio da continuidade administrativa (vide, e.g., Consulta ns. 327,328,332, Relator o Eminente Ministro Neri da Silveira, e ADIn I. 1.805, idem)." (DJ de 20.08.98, seção I, p. 73)

E, no âmbito da Representação elcitoral n. 57 - Distrito Federal, o Ministro Fernando Neves, Relator, ressaltou: "O que me parece importante examinar é se a publicidade institucional vedada temporariamente pelo art. 73 da Lei 1.9 .504 , de 1997, abrange as placas de obras ou serviços em andamento, cuja presença decorre de exigência legal ou contratual e não contenha promoção indevida de autoridades, de servidores ou de administrações. ..... e e registra o eminente jurista: .... Não me parece que essa placa possa estar inchuida na vedação referida, até porque ela atende ao que determina o art. I6 da Lei 5.194, de 1966: Enquanto durar a execução de obras, instalações e serviços de qualquer natureza, é obrigatória a colocação e manutenção de placas visíveis c legíveis ao público, contendo o nome do autor......., assim como os dos responsávcis pela execução dos trabalhos"(TSE D.J. 17/08/98, seção 1, pp. 53/54).

Sob essa óptica, é toda uma equipe governamental e o scu plano que se coloca à apreciação popular. A opinião pública colhida a partir da consulta clcitoral não será, ccrtamente, influenciada pela equipe de segurança que acompanha a autoridade a postular a recondução c, também, muito mais visível, digno, c dotado de maior lisura, o deslocamento com os meios de transporte próprios do cargo que ocupa do que, artilicialmente, por intermédio de equipamentos oferecidos, por vezes, por terceiros, a partir da penumbra.

Isto conduz, fatalmente, a entender como ilusórios os efeitos concretos de grande parte das restrições introduzidas, $\mathrm{cm}$ frontal confronto com a técnica mais 
moderna que recomenda a aplicação da razoabilidade na inserção de limitações a recursos c despesas no âmbito das campanhas elcitorais, alinhando-se isto a um regular e eficicntc sistcma de acompanhamento da alividade fïnanceira e garantia de ampla publicidade."

Evidente que grande parte do resultado da captação de recursos destinase à realização de despesas de publicidade cm campanhas cleitorais; daí a tenclência de inclusão indireta de aportes, por via de mecanismos que, dos bastidores, de forma indireta, podem alimentar e incrementar sua evolução. Rellexo imediato as incessantes tentativas do legislador $\mathrm{cm}$ impor maior rigor às limitações c restrições, até mesmo diante das perspectivas de se alcançar situações de lavorecimento diante da nova tecnologia.

Assim é que, na onda de atualização do texto de regência dos pleitos elelivos e na expectativa de obstaculizar benclícios decorrentes de brechas até então inexistentes, há projetos de tei cm curso visando:

a) regulamentar a propaganda cleitoral por meio de scrviços de valor adicionado e Internet, com o escopo de evitar o abuso do poder econômico (projeto) 2.358/2000, de autoria do deputado Nelson Proença, PMDB-RS);

b) proibir a publicidade de prestadoras de serviços de telelonia que tenham os mesmos números de identificação de partidos políticos, entre 6 de julho e 30 de novembro de 2002 (projeto 4.867/2001, de autoria do deputado Bispo Rodrigues (PL-RJ). ${ }^{62}$

O campo de incidência do controle abarca, não há dúvida, também, as despesas. E, nesse nicho, cabc investigar a par da questão quantitativa, também a ótica da legalidade e da moralidade do dispêndio realizado. São, pois, dois os enfoques reconhecidos e recomendados pelo legislador.

O primeiro, $\mathrm{cm}$ verdade, não oferece maiores dificuldades ao analista. Consubstancia-se num exame acerca da observância dos limites que o próprio partido ou coligação fixou c oficializou (Lei n. 9 504, de 30 de setembro de 1997/ art. 18). ${ }^{.3}$ Impõe-se a verilicação numérica do limite estabelecido, a verificação contábil das despesas

61. Nessa linha a obra de Krache, Rainer, Le financement des Partis Politiques, 1972, Paris, PUF. Sobre o tema, o nosso Finansas Partickirias, 1983, Brasília, Gráfica do Senado Federal.

62. Há outros projetos, da mesma forma relevantes mas que não tocam de perto a questão do linanciamento. Merecem especial registro o projeto de autoria do deputado José Carlos Coutinho (PFLRJ), que visa preservar a moralidade do cargo público, exigindo para o registro da candidatura o exame antidrogas, e o apresentado pelo deputado Aldo Arantes (PC Jo B/GO), de n. 4.404/200I, que obriga os véículos de comunicação a divulgar pesquisas eleitorais conjuntamente, no ensejo de oferecer ao eleitor a possibilidade de análise comparativa e identificar discrepâncias.

63. No quadro doméstico, brasileiro, a fixxação do limite de dispêndios por candidatura é obrigação (lo Partido. figura que deve proceder à declaraçĩo e registro desse dado junto à Jusliça Eleitoral, sujeita a superação desse limite à sanção pecuniciria de multa "no valor de cinco a dez vezes a quantia em excesso." art. $18, \$ 1^{\circ}$ ¿ $2^{\circ}$, Lei n. $9.504 / 97$. 
de campanha que não podem ultrapassa-lo e a investigação real do aspecto geral e do volume da propaganda utilizada, se de conformidade com os números declarados.

O scgundo aspecto, qualitativo, o destino e a finalidade dos gastos, todavia, é o que mais de perto interessa à investigação. É sobre esse especílico campo, nos parece, que o analista deve debruçar sua atenção, porque é nessa esfera que se verificam - ou que se abre a oportunidade para a verificação - de irregularidades que venham a comprometer a lisura da consulta eletiva, a sinceridade do voto, em razão da interveniência dos fatores poluentes que maculam a exteriorização da vontade política expressa na cédula, introduzindo, portanto, máculas sobre o próprio resultado.

Os dispêndios preconizados na lei elcitoral dizem respeito basicamente à publicidade autorizada. Vem, destarte, cuidados nos capítulos que cuidam dessa temática, a partir do art. 36 da assinalada Lei n. 9.504/97. Evidencia-se, aí, uma forte preocupação $\mathrm{cm}$ olerecer tratamento distinto aos dilerentes métodos de marketing conhecidos c pcrmitidos, a exemplo daqueles concretizados por via cartazes, equipamentos de altolalante e amplificadores de som, sistema de outdoor (art. 42), publicidade por via da imprensa (art. 43) e através da mídia (rádio e televisão - arts. 44 a 57).

O legislador, em verdade, buscou assegurar um determinado equilíbrio ao desenvolvimento da campanha, evitando - aliás em homenagem ao próprio princípio inscrito no art. 237 do Código Eleitoral, destinado a inibir a interferência do poder cconômico - excessos resultantes da disparidade de recursos. Nesse diapasão e reconhecendo que períodos longos para a publicidade afiguram-se extremamentc onerosos aos candidatos, consagrou, num primeiro momento, a redução do período de campanha: 3 meses anteriores ao pleito ${ }^{\text {it }}$ para as fórmulas de marketing que não impliquem em radio e televisão e para esses últimos veículos, apenas, 45 dias ${ }^{\text {t.5 }}$

Nessa linha, ainda, a exigência de horário gratuito na rádio e televisão e repartição dos horários, atendendo à densidade eleitoral do partido ou coligação, ou scja cm razão do número de integrantes da(s) respectiva(s) bancada(s) na Câmara dos Deputados ( $\$ 2^{\prime \prime}$, art. 47- Lei n. 9.504/97). E, mais ainda, a partilha dos espaços destinados a outdoors, outra questão espinhosa, que põe em relevo o potencial cconômico, encontrou solução nas regras de distribuição por bandas partidárias, $\mathrm{cm}$ razão da respectiva relevância eleitoral, e por via de sorteio (art. 42 - Lei n. 9.504/97).

No tocante à prática atinente a cartazes, panfletos, banners, etc, o

64. O art. 36 da Lei n. 9.504/97 prevê: "A Propaganda eleitoral somente é permitida apös o dia 5 de jullho do ano da eleição". Considerando que os pleitos se realizam em 3 de outubro - data oficial, isto implica nuın período de cerca de 3 ineses para a campanha publicitária dos candidatos.

65. Este é o prazo fixado pelo art. 47 da Lei n. 9.504/97. 
legislador de 1997 (Lei 9.504/97) seguiu de perto o texto imediatamente anterior ${ }^{\text {r6 }} \mathrm{e}$ autorizou: a fixação de faixas, placas, cartazes, pinturas e inscrições em bens particulares ( $\$ 20$, art. 37), a panfletagem na via pública (art. 38), a realização de comícios (art. 39), a propaganda mediante uso de equipamentos de ampliação do som, no período compreendido entre as 8 e 22 horas, desde que a 200 metros das sedes dos Poderes Públicos e, quando em funcionamento, dos hospitais, escolas, bibliotecas, igrejas e teatros ( $\$ 3 o$, art. 39). E mais, cometeu ao Poder Legislativo - ou mais especificamente à sua Mesa Diretora - a deliberação acerca de atos de marketing eleitoral nas suas dependências ( $\$ 3^{\prime \prime}$, art. 37).

Ao lado desse quadro publicitário, de grande plasticidade quanto aos meios e instrumentos de divulgação, há, é certo, um considerável elenco de vedações, em sua grande parte destinadas a afastar do ambiente eleitoral os fatores de poluição, em especial, o uso da máquina estatal (arts. 37), o desrespeito ao dia de reflexão que é a data da realização das eleições ${ }^{67}$, que deve assegurar um clima que garanta a assepsia do voto ( $\$ 5^{\circ} d o$ art. 39), o uso indevido de símbolos ou imagens governamentais (art. 40), atos de aliciamento (art. $41-A)$. $^{68}$

Técnicas de Controle: um estudo comparativo

O problema trazido a debate constitui, de fato, o ponto nevrálgico desse estudo, girando em torno da questão do financiamento da atividade político-partidárioeleitoral.É que essa vigilância deve, a rigor, se mostrar assecuratória da transparência das operações contábeis, identificando eventuais vínculos, os lobistas e também o destino do dinheiro. Mais, impõe-se que se apresente de simples manuseio, ou seja capaz de operar de forma célere e segura. Demais disso, é necessário que o sistema seja apto a identificar com segurança os responsáveis, porquanto a prática de irregularidade sem a devida sanção - em razão da diluição da responsabilidade - implica num estágio de

\section{Lei 9 100/95.}

67. Um tratamento especial no que concerne ao "Dia da Eleição" já é tradicional em território norteamericano. Entre nós, o legislador, também, lhe oferece um disciplinamento peculiar com vistas a assegurar a livre expressão das preferências políticas. Ver a respeito CAGGIANO, Mônica Herman S., Eleições Municipais de 1996, com ênfase para o quadro de São Paulo, in Revista Jurídica da Procuradoria Geral do Município de São Paulo, ed. da Secretaria dos Negócios Jurídicos da Prefeitura de São Paulo, 1997, pp. 49 a 83.

68. Apesar da preocupação com o Dia da Eleição, certo é que esta data temn demandado significativos recursos financeiros aos promotores de campanhas políticas. É, também, do espectro norte-americano que são extraídos os seguintes dados: Election Day (eleições presidenciais de 1996) - dispêndios do Partido Democrata: US\$250 milhões; Partido Republicano: US\$ 400 milhões. (apud Times, novembro II - 1996, p. 15) 
impunidade que desprestigia qualquer sistema ou técnica de controle, por mais sofisticado que se apresente o seu mecanismo.

Por derradeiro, não poderá o estudioso ignorar a exigência constitucional atinente à garantia da livre manifestação do pensamento e das idéias ${ }^{(6)}$, afastando os excessos - tendência natural de qualquer sistema de controle - que limitem e venham a cingir a atividade do candidato direcionada à expansão de suas propostas, da ideologia e do seu programa.

O método adotado na Alemanha (financiamento pelos cofres públicos ${ }^{70}$ ) é que, sob este aspecto, mais se evidencia, evoluindo para o pedestal de matriz de toda uma linha de tentativas de imitação, sem grande êxito no entanto.

A sua mola mestra consiste em impor financiamento público para as campanhas político-eleitorais, o que implica em identificar perfeitamente o volume e a origem dos recursos. Quanto aos gastos, prevê um ajuste entre as lideranças para a fixação de limites. Em suma a solução germânica, que se destaca, também, pelo tratamento menos proibitivo, repousa sobre aportes públicos e, conseqüentemente, um rígido controle do destino dessas verbas. A prestação de contas, pública, deve se realizar sob os "princípios da correta contabilidade" (art. 28 da Lei dos Partidos Políticos) $)^{71}$

Vale assinalar que o esquema engendrado afigurou-se, de certa forma, eficaz para refrear a desregrada e abusiva ação do dinheiro em ambientes políticoeleitorais; não os tornou imunes, contudo, a episódios de malversação do dinheiro, a exemplo dos fatos, noticiados pela imprensa, a envolver o ex - Chanceler Helmut Kohl? ${ }^{72}$

69. Já no célebre caso Buckley X Vuleo registrava a decisão do Supremno norte-americano "o candidato, não menos que as demais pessoas, encontra-se amparado pelo preceito do Io Aditamento, tendo o direito de participar das discussões acerca dos problemas públicos e advogar; tenaz e incansavelmente, sua eleiçäo...". (v. CAGGIANO, "Finanças Partidárias", op. cit., p. 120).

70. Em terreno brasileiro teın sido intensa a preocupação legislativa no sentido de introduzir um efetivo financiamento público. Ver o projeto de Lei do Senado, n. 353, de 1999, de autoria do Senador Sérgio Machado, com parecer favorável, que, no entanto, continua em tramitação sem qualquer definição quanto a sua futura e eventual transformação em lei.

71. v. CAGGIANO, Finanças Partidárias, op. cit. p 207 e ss.

72. O ex-chanceler alemão Helınut Kohl, que governou a Aleınanha por 16 anos, foi acusado, ao final do ano de 1999, de ter recebido doações políticas, irregulares, destinadas ao seu partido, o CDU (União Democrata-Cristã), criando, para tanto, “contas secretas". (v. nesse sentido, O Estado de São Paulo, ed. de 30.12.99, p. A 14, The Economist, janeiro/fevereiro de 2000, p. 57 e ss., The Economist, Dezembro 11-17/1999, p. 45). A denúncia foi formulada por um ex-tesoureiro do partido, Walter Leisler Kiep, arrolado num processo atinente à evasão fiscal. Deınais disso, está sendo investigada a participação do Presidente da França, François Mitterrand, que teria ordenado o pagaınento de uına "comnissão" para o partido de Kohl, em cenário de campanha eleitoral para reeleição, em 1994, "comissão" esta proveniente da refinaria ELF nas negociações envolvendo a compra e reforma da refinaria aleınã LEUNA. (in The Ecomomist, janeiro/fevereiro de 2000, pp. 57 e ss) 
até hoje sob investigação, em razão de aportes advindos do plano privado para o reforço das finanças eleitorais.

O quadro norte-americano, que nos oferece um vasto repertório de unsavory tales of political money, ${ }^{73}$ hoje se apresenta com um sistema híbrido de controle.

Tendo adotado, em termos facultativos, o financiamento público das campanhas $^{74}$ para os pleitos presidenciais, gira $\mathrm{em}$ torno de limitações alé drásticals - quanto à arrecadação e aos dispêndios. Prevê sanções e o sistema de lisscalização quanto à observância das leis é atribuído à Federal Election Commission, apesar das críticas de que tem sido alvo em razão de sua estrutura considerada frágil. Os PAC's foram legalizados e a legislação dos Estados tem se orientado, nas suas reformas, pelo modelo federal. Mas remanesce em panorama americano o problema das "despesas independentes", isto é de recursos privados que podem advir de particulares ou de PAC's sem qualquer interferência de candidato ou de comitê financeiro, e que podem ser utilizados tanto a favor como contra uma determinada candidatura. E, mais ainda, a questão do "soft money". ou seja o numerário que prescinde de declaração quanto à origem e que pode ser utilizado em eleições locais para uma série de práticas publicitárias - a partir do registro de eleitores, organização das primárias, até a confecção de bottons, cartazes, panfletos, jornais e tablóides partidários, etc. ${ }^{75}$

A seu turno, o modelo francês passou a adotar a opção do financiamento público para as campanhas (cf. quadro final), vedando, a partir de 1995, as contribuições advindas de pessoas jurídicas e de sindicatos. Mas, curiosamente, o legislador de 1995 não mais permitiu computar como despesa de campanha, gastos não autorizados, cxpressamente, pelo candidato; daí, considerando a inexistência de vedação para que comitês simpatizantes de candidaturas promovam seus candidatos, as pessoas jurídicas e físicas passaram a poder realizar doações e financiar tais atividades fora de qualquer controle ${ }^{7 /}$ É a transposição para o cenário francês do modelo "soft money" norte-

73. Repulsivas histórias acerca do dinheiro na política - tradução nossa; ver, ainda, Finanaças Partidárias, op. cit., supra.

74. O financiamento público das campanhas foi uma das bandeiras do Presidente Jimmy Carter, conforme relata HERBERT E. ALEXANDER, Financing Politics, Money, Elections \& Political Reform, $4 a$ ed., Washington, DC, Congressional Quartely Press, Foreword, Fourth Edition, 1992, p. 4I. Ademais foi entendido como uına das inelhores terapias para impedir a corrupção nos ambientes das campanhas eleitorais, após o episódio "Watergate"

75. id. p. 66.

76 cf. MÉDARD, Jean-François, Finanziamento della Política e Corruzione: il caso francese, in Finanziamento della Política e Corruzione, A cura de LANCHESTER, Fulco, Milão, Dott. A . Giuffrè Editore, 2000. 
americano e essa inspiração parece mais evidente ainda se traçado um paralelo com o PAC's, que pode ter inspirado o legislador. De qualquer modo, este mostrou-se mais restritivo do que a regulamentação tedesca, porquanto proíbe contribuições de origem estrangeira e fixa limites para dispêndios por parte dos candidatos, como também no tocante às doações, impondo ainda a sua declaração, mediante registro.

No cenário italiano, após o episódio conhecido como "Tangentopoli", que desvendou uma extensa rede de corrupção envolvendo políticos, empreiteiros c intermediários, diversas foram as tentativas de se introduzir uma adequada regulamentação do quadro partidário, incluindo a questão do linanciamento da atividade política.

A idéia de fïnanciamento público,aliás, foi acolhida em 1974, com o advento da Lei n 195; transcorrido um período de intensa nebulosidade, porém, em 1997 o legislador introduziu um novo modelo: "o financiamento voluntário dos partidos políficos" (lei n. 2, de 1997), sem abandonar a idćia de financiamento público que passou a constar como norma transitória, inserida, por vezes até em textos legais de matiz tributário ${ }^{77}$

A perspectiva de edição de novo texto, promovendo o retorno ao financiamento público das atividades dos partidos e movimentos, foi alcançada com a edição da Lei n. 157, de 3 de junho de 1999, que dispôs sobre "Nuove norme in matéria di rimborso delle spese per consultazioni elettorali e referendarie e abrogazione delle disposizioni concernenti la contribuzione volontaria ai movimenti e partiti politici"

Porém, perdura, na Itália, a preocupação com a ausência de regulamentação a nortear e disciplinar a atuação dos partidos e movimentos, ganhando simpatia a proposta legislativa de Mancina (Ato Câmera n. 5.326, de 20 de outubro de 1998), que preconiza "Normas sobre a democracia interna dos partidos, sobre a seleção dos candidatos e sobre o financiamento" 78

Quanto aos mecanismos adotados em terreno brasileiro, o padrão permanece fiel ao método das limitações e controles relativos. Os limites quanto às doações são pertinentes à pessoa física. O teto estabelecido para pessoas jurídicas vem apresentado em proporção ao respectivo faturamento bruto do ano anterior à eleição. Nada

77. De fato, a Lei italiana de n. 146, de 8 de maio de 1998, que cuidava da simplificação e racionalização do sistema tributário para o funcionamento da Administração Fazendária, trazia um dispositivo - art. 30, que previa a dotação de 110 milhões de liras a favor de movimentos e partidos políticos. (cf. FROSINI, Tommaso Edoardo, Finanziamento Dei Partiti e Corruzione: Brevi Note Critiche sul Caso Italiano, in Finanziamento della Política e Corruzione, A cura de LANCHESTER, Fulco, Milão, Dott. A . Giuffrè Editore, 2000, p. 424.

78. cf. FROSINI, Tommaso Edoardo, ibidem, p. 411 e ss. 
alćm disto. ${ }^{79}$ Os limites de gastos, para a realização de campanhas eleitorais, os próprios partidos apontam (art. 18, caput, Lei n. 9 504/97). É vedada a contribuição financeira oriunda de entidade ou governo estrangeiro ou que tenha lastro estrangeiro. São afastados os recursos que possam vir canalizados do erário público, excetuado os do Fundo Partidário, mecanismo de financiamento que busca implantar aqui o padrão germânico.

Com efeito, a idéia de financiamento público das campanhas, seguindo a matriz alemã, tem conquistado um número considerável de adeptos, principalmente, em razão da ampla possibilidade de controle (pelo Tribunal de Contas da União) e, portanto, em face da idéia de garantia de maior transparência que oferece. Esse Fundo, disciplinado por força da Lei Orgânica dos Partidos Políticos (Lei n. 9.096, de 19 de setembro de 1995 - art. 38), iniciou sua trajetória de forma extremamente tímida. Criado em 1965 (Lei n. 4.740/65), foi reforçado no tocante à sua constituição pelo diploma editado em 1971 (Lei n. $5.682 / 71$ ) e, remodelado o conteúdo por força da atual LOPP (art. 38), é objeto, hoje, de proposta de reforma de lege ferenda. Nesse sentido, o projeto de Lei do Senado, n. 353, de 1999, de autoria do Senador Sérgio Machado, com parecer favorável, que, no entanto, continua em tramitação sem qualquer definição quanto a sua futura e eventual transformação em lei.

De outra parte, embora, tenha apresentado um volume de recursos maior do que nas primeiras décadas de sua existência, o Fundo Partidário, ainda, não oferece um suporte adequado para poder suportar o elevado custo do voto ${ }^{80}$ Assim é que, a

79. Art. 81 da Lei n. 9.504/97. Interessante, além disso, é verificar os principais financiadores das campanhas do ex-presidente da República Federativa do Brasil, Fernando Henrique Cardoso: Banco Itaú 2.6 milhões de reais; La Fonte Investimentos - I milhão de reais; Grupo Bradesco - I milhão de reais; Banco Real e Banco Real de Investimentos - I milhão de reais; Companhia Brasileira de Petróleo Ipiranga - I milhão de reais; Inepar - Indústria e Construções - I milhão de reais; Copesul - Companhia Petroquímica do Rio Grande do Sul - I milhão de reais; Volkswagen Serviços - 0,8 milhão de reais; Florestas Rio Doce - 0,75 milhão de reais; Vale do rio Doce Alumínio (Aluvale) - 0,75 milhão de reais; Estrel Administração e Corretagem de seguros - 0,6 milhão de reais; Gerdau S. A . - 0,6 milhão de reais; Banco Safisa S. A . - 0,6 milhão de reais; BBA Trading - 0,5 milhão de reais; Petroquímica do Nordeste (Copene) - 0,5 milhão de reais; Banco Real - 0,5 milhão de reais; Techint Engenharia - 0,5 milhão de reais; Construtora Andrade Gutierrez - 0,5 milhão de reais. (conforme registros do jornal O Estado de São Paulo, edição de 26.1 1.98/ Fonte:TSE). E, mais até, em relação à campanha de 2002, o Jornal Valor (ed. de lo de janeiro de 2003) veicula a seguinte lista dos maiores colaboradores da campanha político eleitoral: Grupo Odebrecht - R\$ 3,286 bilhões; Grupo Votorantim - R\$1.717.954,00; Usina Caeté - R\$ 1.228.521,00; Grupo Itaú - R\$1,186 bilhão; Gerdau - R\$ I, 68 bilhão; Aracruz - R\$ I.110.000,00; Klabin - R\$ 1.078.959,00; Instituto Brasileiro de Siderurgia - R\$ 1,050 bilhão; Suzano - R\$ 989.325,00; OAS - R\$ 974.868,00; Embraer - R\$ 815 mil; Coca-Cola - R\$ 768.964,00; Companhia Vale do Rio doce - R $\$ 740$ mil; Embratel - R\$ 700 mil; Safra - R\$ 685 mil; Bovespa - R\$ $532 \mathrm{mil}$; Ambev - R\$ 500 mil; lpiranga - R\$ 485,5 mil; Usiminas - R\$460,9 mil.

80. O volume de recursos advindos do Fundo Partidário (solução brasileira para o público financiamento das atividades político-partidárias-eleitorais) vem, de fato, se ampliando nos últimos anos, não mais apresentando o tradicional tom anêmico. Cf. dados registrados pelo TSE. 
consulta eleitoral, a nível municipal, envolveu um custo de cerca de 2 bilhões de reais, enquanto o Fundo Partidário distribuiu apenas $\mathrm{R} \$ 70.224 .978,61$ (cf. dados do TSE)

Certo é que, o nosso sistcma busca respaldo na técnica das vedações (acima especificadas) e na idealização de um mecanismo de controle que, a par do registro das doações, exige escrituração contábil e uma prestação de contas ao final de cada pleito. Tudo sob o comando da Justiça Eleitoral, responsável pela fiscalização e pelo atendimento da lei nos períodos eleitorais.

A engrenagem visualizada pelo legislador, porém, ainda não configura o sistema ideal, haja vista o elenco de casos de espúria canalização do dinheiro nesses períodos. Isto, em parte, em razão das vedações excessivas que pressionam em demasia partidos e candidatos, conduzindo as finanças político-partidárias-eleitorais a transitar por uma via marginal, ilegal. E, de outro, porque diante da ausência de um financiamento público de difícil prática num país com um crário deficitário e onde o voto tem um clevado preço - a imposição de transparência ć que deveria ser merecedora de maior atenção c privilégio, idealizando-se mecanismos de incentivo às doações registradas $\mathrm{c}$ destinadas a partidos políticos ou candidatos, de molde a, ao menos, aclarar ao cleitor quem ou que potência econômica encontra-se nos bastidores da candidatura objeto dc sua opção política.

Por derradeiro e resultado da pesquisa realizada, é apresentado um quadro ilustrativo do tratamento dessa questão financeira a envolver partidos políticos c campanhas cleitorais em alguns dos ordenamentos jurídicos que foram abordados na produção deste trabalho:

\begin{tabular}{|c|c|c|c|c|c|c|}
\hline País & $\mathrm{A}$ & $\mathrm{B}$ & $\mathrm{C}$ & $\mathrm{D}$ & $\mathrm{E}$ & $\mathrm{F}$ \\
\hline Bélgica & Sim & Não & Sim & US\$125 & Sim & Sim \\
\hline Brasil & Pouco & $\begin{array}{c}\text { Só pessoas } \\
\text { Jurídicas }\end{array}$ & Não & $\begin{array}{c}\text { Pessoas } \\
\text { Físicas } \\
\text { lo\% do rend. } \\
\text { Bruto. }\end{array}$ & $\begin{array}{c}\text { O limite } \\
\text { declarado }\end{array}$ & Sim \\
\hline Inglaterra & Não & Sim & Sim & Não & Recomendo & Não \\
\hline Rep. Checa & Sim & Sim & Sim & US\$2.800 & Não & Não \\
\hline França & Sim* & Não** & Não & US\$150*** & Sim**** & Sim \\
\hline Itália & Sim & Sim & Sim & US\$2 600 & Sim & Sim \\
\hline Espanha & Sim & Sim & Não & Sim & Sim & Sim \\
\hline Alcmanha & Sim & Sim & Sim & US\$10.300 & Não & Sim \\
\hline Japão & Sim***** & Sim & Não & US\$475 & Sim & Sim \\
\hline Sućcia & Sim & Sim & Sim & Não há & Não & Sim \\
\hline USA & Sim & Sim $* * * * * *$ & Não & US\$250 & Sim & Sim \\
\hline
\end{tabular}


Na tabela:
A: Financiamento Público
B: Doações de pessoas jurídicas e sindicalos
C: Doações provenientes do estrangeiro
D: Limites de Doações (obrig. de declarar publicidade)
E: Limites de Despesas
F: Prestação de Contas

* Un dos mecanisnos adotados pela reforma de 1995 consiste no público financiamento dos partidos e das campanhas eleitorais, mediante um reembolso pelo Estado de 50\% do respectivo teto limite de despesas, mecanismo que beneficia apenas os partidos que conquistaram $5 \%$ dos votos. Em 1995, de acordo com tais regras, foi repassado um total de 526 milhões de francos, distribuidos a partir da divisão de metade desse valor de acordo com o desempenho nas eleições gerais para a Assembléia Nacional e a segunda metade em razão do mimero de parlamentares filiados ao partido. (cf. Jean-François Médard, Finanzianento della Política e Corruzione: il caso francese, in Finanziamento della Política e Corruzione, A cura de LANCHESTER, Fulco, Milão, Dott. A Giuffrè Editore, 2000).

** desde 1995 e há exceções.

*** cada candidato pode receber o valor máximo de 30.000 francos por doador e os partidos podem receber o montante máximo de 50.000 francos por ano de cada contribuinte (La France aux Urnes)

**** Para as eleições presidenciais: 120 milhões de francos e para as eleiçôes legislativas 250.000 francos por candidato. ((cf. Jean-François Médard, Finamziamento della Política e Corruzione: il caso francese, in Finanziamento della Política e Corruzione, A cura de LANCHESTER, Fulco, Milão, Dott. A . Giuffrè Editore, 2000).

$* * * * *$ desde 1994

****** a legislação de alguns Estados permite.

Fonte base: The Economist, janeirolfevereiro 2000, p. 57. (dados acrescidos de acordo com pesquisas em outras bases, acina referidas)

São Paulo, julho de 2003. 
Bibliografia Básica:

ALEXANDER, Herbert E., "Financing Politics-Money Elections and Political Reform, Washington, DC, Congressional Quartely Press, Foreword, Fourth Edition, 1992, p.3

CAGGIANO, Monica Herman, "Eleições Municipais de 1996, com ênfase para o quadro de São Paulo" in Revista Jurídica da Procuradoria Geral do Município de São Paulo, ed. da Secretaria dos Negócios Jurídicos da Prefeitura de São Paulo, 1997 "Finanças Partidárias, Brasília, Editora do Senado Federal, 1983. Sistemas Eleitorais X Representação Política, Brasília, Senado Federal, 1991.

DAHL, Robert. Qui Gouverne, trad. de Pierre Birman e Pierre Birnbaum, Paris, Librairie Armand Colin, 1971, p.1.

DEMICHEL, André e Francine, (Droit Électoral, LD. Paris, 1973)

DUVERGER, Maurice. Institutions Politiques et Droit Constitutionnel, Paris, PUF, 1971

FERREIRA FILHo, Manoel Gollçalves. "Sete Vezes Democracia" São Paulo, Ed., Convívio, 1977.

FROSINI, Tommaso Edoardo. Finanziamento Dei Partiti e Corruzione: Brevi Note Critiche sul Caso Italiano, in Finanziamento della Politica e Corruzione, A Cura de LANCHESTER Fulco, Milão, Dott. A. Giuffre Editore, 2000

KRAEHE, Rainer, Le financement des Partis Politiques, Paris, PUF, 1972

LEMBO, Claudio, Participação Política e Assistência Simples, Rio de Janeiro, Forense Universitária, 1991.

LOEWENSTEIN, Karl. “Teoria de La Constitución”, Barcelona, Ed. Ariel, 1976. MACLET, Claude. (Droit Électoral, PUF, Paris, 1989).

MANOD, Alain, Le Financement des Campagnes Électorales, Paris, Berger Levrault, setembro de 2000

MÉDARD, Jean-François, Finamziamento della Política e Corruzione: il caso francese, ini Finanziamento della Política é Corrruzione, A cura de LANCHESTER, Fulco, Milão, Dott A. Giuffrè Editore, 2000 